\title{
Movements of electronically tagged shortfin mako sharks (Isurus oxyrinchus) in the eastern North Pacific Ocean
}

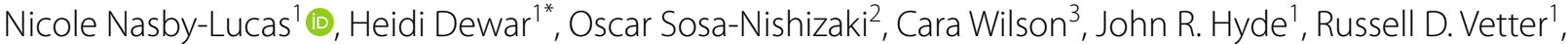 \\ James Wraith ${ }^{1}$, Barbara A. Block ${ }^{4}$, Michael J. Kinney ${ }^{1}$, Tim Sippel ${ }^{1}$, David B. Holts ${ }^{1}$ and Suzanne Kohin ${ }^{1}$
}

\begin{abstract}
Background: Most information on shortfin makos (Isurus oxyrinchus) in the eastern North Pacific (ENP) currently comes from fisheries data and short-term tracking studies. Although range has been inferred from catch and conventional tag data, little is known about the migration patterns and behavior in the ENP. This long-term electronic tagging study was designed to examine in detail the movement patterns and behavior of mako sharks in the ENP.

Results: In this study, a total of 105 mako sharks (104-280 cm fork length) were successfully tagged in the California Current between 2002 and 2014 with Argos satellite tags, including 93 satellite-linked radio-transmitting (SLRT) tags and 71 pop-up satellite archival tags (PSATs). This included 29 males that are in the size range of maturity, but only one mature female. Mean track durations from SLRT data were 337 days ( $\max 1025$ ), and PSAT tags were 136 days (max 272). Estimated minimum distance traveled in 1 year ranged from 6945 to 18,800 km/year. Habitats utilized included the entire California Current, the Sea of Cortez and offshore in the areas of the North Pacific Subtropical Gyre, North Pacific Transition Zone and North Equatorial Current. Seasonal movements within the California Current coincided with periods of higher primary productivity and chlorophyll $a$, and sea surface temperatures (SSTs) between 15 and $25^{\circ} \mathrm{C}$. SST ranged from 11 to $31^{\circ} \mathrm{C}$ throughout the range, indicating a broad thermal tolerance.

Conclusions: Some of the key findings include the discovery of a high degree of variability between individuals in their vertical and horizontal movements, a strong influence of body size and season on mako shark movements, and the repetitive use of certain areas by individuals. These results expand our understanding of the distribution of mako sharks in the ENP. Although mako sharks are thought to comprise a single stock throughout the North Pacific, horizontal distribution of tagged mako sharks in this study was limited to the ENP demonstrating some spatial substructure. This study provides important data that can be used to identify fishery and gear vulnerabilities and inform management.
\end{abstract}

Keywords: Shortfin mako, Habitat preferences, Migration, Behavior, Pacific

\section{Background}

The development of electronic tags has revolutionized the study of highly migratory species, such as sharks, and enables collection of data on movements and behaviors over multiple years. One species in particular that has proved to be an excellent platform for fin-mounted

\footnotetext{
*Correspondence: heidi.dewar@noaa.gov

${ }^{1}$ Southwest Fisheries Science Center, National Marine Fisheries Service, National Oceanic and Atmospheric Administration, San Diego, CA, USA Full list of author information is available at the end of the article
}

satellite tags that transmit when the shark is at the surface is the shortfin mako (Isurus oxyrinchus) (hereinafter referred to as mako shark). Mako sharks seasonally occur in coastal regions, but their movements and behaviors away from the coast have been difficult to determine. There have been numerous studies conducted around the world using satellite tags on mako sharks to provide insight into distribution, behavior, and habitat use throughout their range [1-5]. We report here on the 
largest of these studies to date, which was conducted in the eastern North Pacific (ENP).

The mako shark is a pelagic predator with a worldwide distribution from temperate to tropical waters. With a fusiform shape (lamniform) and lunate tail, the mako shark is one of the fastest pelagic predators, with anecdotal reports of top speeds exceeding $50 \mathrm{~km} / \mathrm{h}$ and individual sharks routinely traveling distances greater than $50 \mathrm{~km} /$ day [2, 5, 7-9]. Like its lamnid relatives, including the white shark (Carcharodon carcharias), the mako shark is equipped with countercurrent heat exchangers, which enable it to maintain internal temperatures several degrees above ambient water temperature [10-13]. Endothermy enhances muscle and digestive performance and provides advantages enabling mako sharks to better exploit fast-moving prey. The diet of mako sharks off California includes highly mobile pelagic prey such as jumbo squid (Dosidicus gigas), Pacific saury (Cololabis saira), Pacific sardine (Sardinops sagax), Pacific chub mackerel (Scomber japonicus), tuna (Thunnus spp.), other sharks, and for larger mako sharks, marine mammals [14, 15] indicative of a eurythermal shark capable of a foraging on a wide variety of prey.

Mako sharks are caught in commercial and recreational fisheries in the ENP with their high muscular performance and activity levels contributing to their popularity as a sport fish. In the US commercial high-seas longline and California large-mesh drift gillnet fishery, they are caught incidentally but are typically landed and commercially sold. In Mexican waters, mako sharks are caught by middle size and artisanal fisheries along the western coast of the Baja California Peninsula [16-18]. Globally, mako sharks make up a significant proportion of sharks in the international fin trade [19]. Similar to many shark species, mako sharks are vulnerable to overfishing due to their slow growth, late age of maturity, and low fecundity [20, 21]. The first length-based, age-structured, fully integrated model for this species in the North Pacific was completed in 2018. It indicated that makos are not being overfished and that overfishing is not occurring [22]. In contrast, in the North Atlantic the most recent assessment estimated that mako sharks are overfished and that overfishing is occurring [23]. The International Union for Conservation of Nature (IUCN) lists mako sharks as endangered worldwide [24]; however, this global listing is likely of limited use as indicated by the contrast in stock status which highlights the fact that the status of the species is variable across oceans.

Current information on the distribution, stock structure, and habitat use of mako sharks in the ENP is derived primarily from genetics, fishery, and conventional and acoustic tagging studies [7, 8, 25-29]. Genetic analyses suggest a single population across the North Pacific [25,
26]. In the ENP, the range of mako sharks has been primarily inferred from catch and conventional tag data. These data indicate that they typically occur in coastal regions seasonally, but their movements and behaviors away from the coast have been difficult to determine. Based on fisheries data, their distribution in the ENP encompasses the temperate North Pacific from the coast of southern Washington to Baja California, Mexico, and across the Pacific Ocean to Japan and Taiwan. Conventional tag data show that although the majority of makos tagged in Southern California are recaptured locally (total recaptures $n=317$, a small number have been caught elsewhere, including near Acapulco $(n=1)$ to the south and in the western Pacific toward Hawaii and Japan $(n=8)[29]$.

In the ENP, the Southern California Bight (SCB; the area from Point Conception to Punta Colonet, just south of the US/Mexican border, and including the area surrounding the Channel Islands) appears to be an important habitat for mako sharks across size classes. Young-of-the-year (YOY) (age-0, defined as sharks less than $100 \mathrm{~cm}$ fork length (FL) $[29,30])$ and juvenile mako sharks comprise the majority of fisheries catch, suggesting that the SCB is a nursery area, although catch composition may also be influenced by gear selectivity. While smaller sharks dominate the catch, large individuals, including mature males and females, are also encountered [31-33].

While these datasets provide a general view of the distribution and size structure of mako sharks along the West Coast of North America, data gaps remain. The available data are limited in time and space and are primarily fisheries dependent. While acoustic telemetry studies have been performed within the SCB and provided data on short-term movements, behaviors and foraging patterns $[7,8,27]$, these tracks do not provide insight into large-scale and seasonal movements and provide little information on mako shark distribution or habitat use outside the California Current. Thus, for a large portion of the year, the predominant habitat of mako sharks is unknown. An additional challenge is that the majority of data are for small or immature sharks. Conventional tags provide no information between tagging and recovery, have a low recovery rate $(6.5 \%[28])$, and provide minimal insights into large-scale migratory patterns. Without information on movements across extended timeframes, it is difficult to determine seasonal patterns, the degree to which mako sharks interact with different fisheries, the scale of movements, changes in movement pattern with ontogeny, and whether individuals return annually to specific locations. Filling these data gaps is critical for sustainable management, especially as we move toward ecosystem-based management schemes. 
We report here on a long-term satellite tagging study of mako sharks in the ENP that was conducted as a part of the Tagging of Pacific Pelagics (TOPP) program [34]. The primary objectives of this long-term study were to examine (1) residency within the SCB, (2) seasonal movement patterns, (3) temperature and depth preferences, (4) long-term movements in relation to oceanographic conditions within and outside the California Current Region, and (5) movement patterns in relation to international boundaries and the distribution of fisheries. Subsets of this rich dataset have been used in previous publications $[9,34-38]$. This paper is intended as a first description of this large dataset; further in-depth analyses to examine movement with respect to environmental parameters are planned for companion publications.

\section{Results}

\section{Data recovery and track durations}

A total of 105 mako sharks were successfully tagged (i.e., provided some data) between June 2002 and June 2014 including 60 males from 104 to $260 \mathrm{~cm} \mathrm{FL}(165 \pm 34 \mathrm{~cm}$, mean \pm SD throughout, unless otherwise indicated), 43 females from 107 to $280 \mathrm{~cm} \mathrm{FL}(169 \pm 36 \mathrm{~cm})$, and two sharks of unknown sex of 236 and $275 \mathrm{~cm}$ FL (Additional file 1: Table S1, Fig. 1). This included 53 small sharks (<165 cm FL; 31 males, 21 females) and 52 large sharks (>165 cm FL; 29 males, 22 females, two sex unknown) with 29 males that are in the size range of maturity, but only one mature female. All but four sharks were tagged in the SCB (Fig. 2).

Satellite-linked radio-transmitting (SLRT) tags were deployed on 93 mako sharks, of which all but four transmitted data. The 89 tags that reported included 39 small sharks (104-163 cm FL) and 50 large sharks $(167-280 \mathrm{~cm}$ FL) (Additional file 1: Table S1). A total of 62 tracks were greater than 6 months (20 small, 42 large sharks; 30 female, 32 male sharks) and 36 were greater than 1 year (8 small, 28 large sharks; 18 female, 18 male sharks) (Additional file 1: Table S1). Mean track duration was $337 \pm 243$ days ( $\max 1025)$, with tracks for small sharks (226 \pm 176 days, $\max 697$ ) significantly shorter than for large sharks (424 \pm 254 days, max 1025) (Mann-Whitney rank-sum test, $U=503.5, n_{1}=50, n_{2}=39, p=0.0001$ ). The number of locations per day ranged from 0 to 16 with gaps from 1 to 140 days (median 2 days). After tracks were filtered to include only the high-accuracy daily position, $83 \%$ of location classes were 1,2 , or 3 .

Pop-up satellite archival tags (PSATs) were deployed on 71 mako sharks, of which 16 either did not report or did not provide usable data. The remaining 55 tagged sharks included 34 small sharks (104-163 cm FL) and 21 large sharks (168-260 cm FL) (Additional file 1: Table S1). Deployment durations ranged from 3 to 272 days
(129 \pm 73 days) with 37 tracks $\geq 90$ days (19 small, 18 large sharks). Of the 55 PSAT tagged sharks, 39 were double-tagged providing corresponding SLRT position data. Light-based geolocation provided movement data for the other 16 sharks. Twenty-five of the tracks from doubletagged sharks were between 3 and 8 months ( 9 small, 16 large sharks). Ten PSATs were recovered and provided 18-224 (total 1039) days of high-resolution archival data. Depth records from 6 of the 55 sharks tagged with PSAT tags were consistent with a mortality event. One shark sank to $280 \mathrm{~m}$ for 3 days, 3 days after release, likely indicating a post-release mortality. Five other sharks sank after deployments of between 79 and 240 days. These five mortality events were not considered to be associated with tagging. Two double-tagged sharks provided no data from either tag, while this is suggestive of mortality, their fate could not be definitively determined.

\section{Horizontal movement}

The movements of SLRT-tagged makos covered a large portion of the ENP. The pop-off points of the PSATtagged sharks were also within this range. The extent of latitudinal movements along the coast $\left(47^{\circ} \mathrm{N}\right.$ to $\left.3^{\circ} \mathrm{N}\right)$ spanned from Washington State to just south of Puerto Vallarta, Mexico, and in offshore waters from the Equatorial Counter Current to the North Pacific Transition Zone (NPTZ). Overall longitudinal range extended from the coast out toward the Hawaiian Islands $\left(105^{\circ} \mathrm{W}\right.$ to $155^{\circ} \mathrm{W}$ ) (Fig. 3). The farthest movements to the west occurred between 12 and $20^{\circ} \mathrm{N}$ with large sharks extending to $155^{\circ} \mathrm{W}$ and small sharks reaching $142^{\circ} \mathrm{W}$. Two female sharks (173 and $182 \mathrm{FL}$ ) traveled the farthest south to 2.8 and $4.2^{\circ} \mathrm{N}$ (Fig. 3). Five male sharks (147-187 $\mathrm{FL})$ traveled the farthest to the northwest, moving to $142^{\circ} \mathrm{W}$ off the coast of Oregon and Northern California between 37 and $46^{\circ} \mathrm{N}$ (Fig. 3). Mean rate of movement was significantly different between small and large sharks ( $t$ test, $t=5.0, d f=85, p<0.0001$ ) with small sharks averaging $23.2 \pm 17.4 \mathrm{~km} /$ day with a $\max$ of $109.2 \mathrm{~km} /$ day and large sharks averaging $31.8 \pm 22.3 \mathrm{~km} /$ day with a max $142.4 \mathrm{~km} /$ day. Estimated distance traveled for sharks with tracks greater than 1 year $(n=36)$ ranged from 6945 to $18,800 \mathrm{~km} /$ year.

Monthly and seasonal movement patterns were apparent (Figs. 3, 4, 5). Large and small sharks were found in the SCB region most frequently during the months of July through September. In September through November, sharks began to disperse both offshore and to the north and south along the coast, ranging from Washington to near Magdalena Bay, in southern Baja California, Mexico. From December through May, sharks in the California Current moved south, occurring predominantly between 

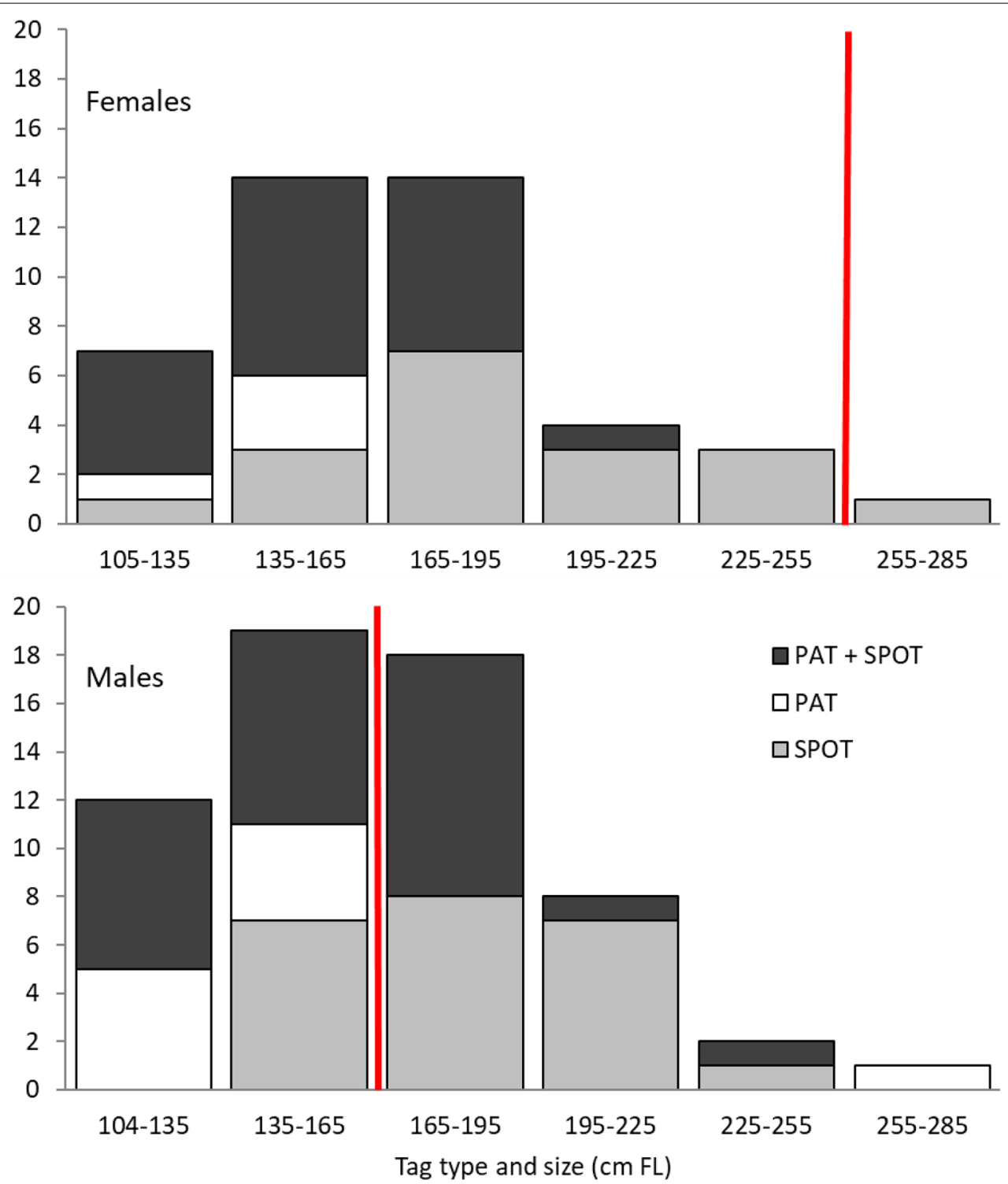

Fig. 1 Size and sex distribution of successfully tagged mako sharks indicating the type of tag(s) deployed. The red line approximates the estimated length of maturity for male and female mako sharks. There were an additional two PSAT tagged sharks of unknown sex not included in the figure (236 and $275 \mathrm{~cm} \mathrm{FL)}$

Central California and tip of the Baja Peninsula. Larger sharks ventured farther offshore. Offshore data showed areas of higher use toward the Hawaiian Islands between 12 and $20^{\circ} \mathrm{N}$ (Fig. 5), with an increase in presence offshore during December-June. Most sharks returned to the SCB during June-August.

Differences in movements were apparent between size classes. The overall range of movement was greater for large sharks both north-south (large: $2.8^{\circ} \mathrm{N}$ to $47.4^{\circ} \mathrm{N}$, small: $9.9^{\circ} \mathrm{N}$ to $45.7^{\circ} \mathrm{N}$ ) and west (large: $155.4^{\circ} \mathrm{W}$, small: $142.0^{\circ} \mathrm{W}$ ) (Fig. 6a, b). Mean monthly longitudes by size were significantly different $(t$ test, $t=7.0, d f=22$, $p<0.0001$ ), while mean monthly latitudes were not ( $t$ test, $t=0.8, d f=22, p=0.43)$. The difference in range north-south despite the fact that they were not statistically significant is primarily due to a few outliners, with the females that travelled as far south as $3^{\circ} \mathrm{N}$ in the region of the Equatorial Countercurrent. This highlights the fact that even with some common patterns, the overall range of movements varies across individuals.

\section{General habitat preferences}

Depth and temperature data from the PSATs were used to characterize habitat use. Across regions, makos ranged 


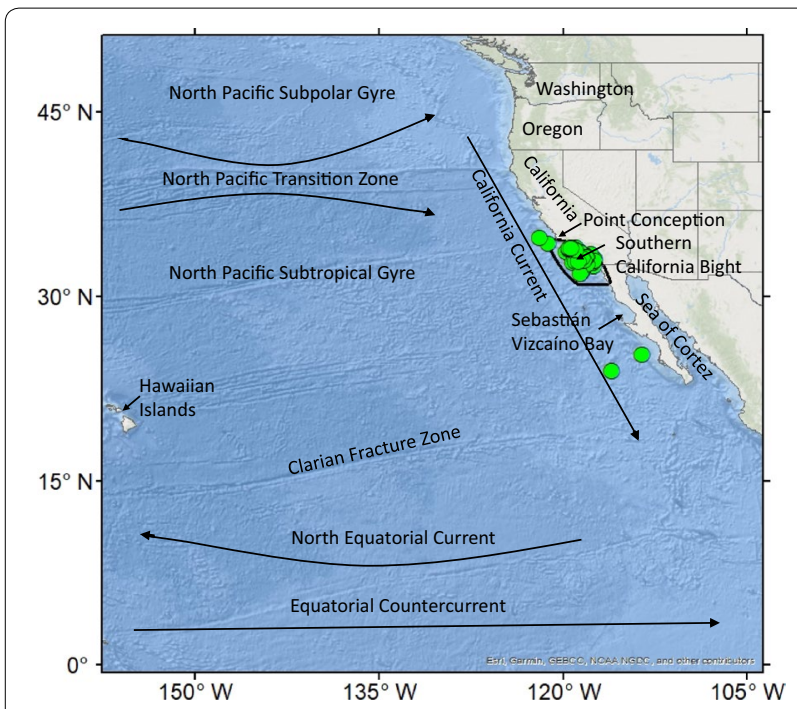

Fig. 2 Map of the eastern North Pacific with mako shark tagging locations shown as green circles. Relevant oceanographic features and geographic locations are indicated

from the surface to depths exceeding $700 \mathrm{~m}$. Mean maximum depths were $402 \pm 143 \mathrm{~m}$ for large sharks (range $248-700 \mathrm{~m}$ ) and $302 \pm 58 \mathrm{~m}$ for small sharks (range 200$500 \mathrm{~m}$ ) and were significantly different (Mann-Whitney rank-sum test, $U=65.5, n_{1}=19, n_{2}=18, p=0.001$ ). Maximum depths did not differ significantly by sex between large males and females and small males and females (Mann-Whitney rank-sum test, small $U=30.5, n_{1}=10$, $n_{2}=9, p>0.25$ and large $U=33, p>0.65$ ). The majority of time was spent in the top $50 \mathrm{~m}$ for both size classes (large sharks 88.2\%: small sharks 90.2\%). Ambient water temperatures recorded ranged from 5.3 to $30.2{ }^{\circ} \mathrm{C}$. The coldest temperatures were associated with the deepest dives. Mean minimum temperatures were $7.3 \pm 1.1^{\circ} \mathrm{C}$ for large sharks (range $5.3-8.8^{\circ} \mathrm{C}$ ) and $8.5 \pm 1.1{ }^{\circ} \mathrm{C}$ for small sharks (range $6.8-11.6{ }^{\circ} \mathrm{C}$ ) and were significantly different (Mann-Whitney rank-sum test, $U=164.5, n_{1}=19$, $n_{2}=18, p=0.001$ ). The majority of time was spent from 14 to $22^{\circ} \mathrm{C}$ for both size classes (large sharks $75.7 \%$, small sharks $80.7 \%$ ).

Using filtered SLRT positions to delineate habitat utilization, the sea-surface temperature (SST) extracted from satellite imagery indicated mako sharks utilized SSTs from 11.2 to $31.2{ }^{\circ} \mathrm{C}\left(18.9 \pm 3.5{ }^{\circ} \mathrm{C}\right)$ (Fig. 7), with variability associated with region and time of year (see below). The highest SST values were within the Sea of Cortez (SOC) and the lowest between northern California and Washington. The mean SST experienced by SLRT-tagged sharks and PSAT-tagged sharks was similar, but the range was greater for SLRT-tagged sharks which had longer tracks and traveled over a broader range than PSAT-tagged sharks including into the SOC. Mean primary productivity values were $6.5 \pm 0.7 \mathrm{mg}$ $\mathrm{C} \mathrm{m}^{-2}$ day $^{-1}$, and chlorophyll a (Chl-a) values were $0.5 \pm 0.8 \mathrm{mg} \mathrm{m}^{-3}$. The highest levels of primary productivity (>6.5 $\mathrm{mg} \mathrm{C} \mathrm{m}^{-2}$ day $^{-1}$ ) and Chl-a $\left(>0.5 \mathrm{mg} \mathrm{m}^{-3}\right.$ ) were found in coastal waters from Washington to mainland Mexico and into the SOC, while the lowest levels were found offshore (Fig. 7, Table 1). Hovmöller plots (latitude or longitude versus time) show movements within the California Current coastal region in relation to SST, Chl-a, and primary productivity (Fig. 8). Seasonal range expansions to the north in the summer and fall and the south in the winter and early spring were coincident with periods of higher productivity and Chl-a in these regions. Movements also corresponded with warming in the north and cooling in the south with sharks occurring primarily at SSTs between 15 and $25^{\circ} \mathrm{C}$.

Diel behavioral patterns were examined using highresolution archival data from PSATs $(n=10)$. Data for small and large sharks were not significantly different (two-sample Kolmogorov-Smirnov test, $D=0.3, p=0.6$ ) and were combined for all analyses. The combined depth histograms showed that $48 \%$ and $55 \%$ of time was spent in the top $10 \mathrm{~m}$ during the day and night, respectively, $13 \%$ and $4 \%$ of time was spent below $50 \mathrm{~m}$ during the day and night, respectively, with $2 \%$ and $0.07 \%$ below $150 \mathrm{~m}$ during the day and night, respectively (Fig. 9a). Temperature histograms showed that $78 \%$ and $90 \%$ of time was spent between 14 and $22{ }^{\circ} \mathrm{C}$ during the day and night, respectively, with $13 \%$ and $2 \%$ of time spent in waters colder than $14{ }^{\circ} \mathrm{C}$ during the day and night, respectively (Fig. 9b). Based on the recovered time-series data, maximum depth per day was significantly deeper during the day than at night (day $125.7 \mathrm{~m} \pm 96.6$, night $58.6 \pm 55.3$ ) (Mann-Whitney rank-sum test, $U=708,495.5, n_{1}=950$, $\left.n_{2}=949, p<0.0001\right)$. Similarly, minimum temperature per day was significantly cooler during the day than at night (day $11.9{ }^{\circ} \mathrm{C} \pm 3.1$, night $14.7{ }^{\circ} \mathrm{C} \pm 2.7$ ) (MannWhitney rank-sum test, $U=209,125.5, n_{1}=950, n_{2}=949$, $p<0.0001$ ). The mean mixed layer depth (MLD) for all 10 recovered tags was $18.6 \mathrm{~m}$ (minimum $11 \mathrm{~m}$, maximum $31 \mathrm{~m})$.

While general patterns among individuals were apparent, fine-scale vertical behavior for individual sharks varied within and between regions. Dive patterns for a single shark are shown in Fig. 10. Within the SCB, the shark's behavior included days when it spent the majority of the time day or night near the surface (Fig. 10a), and others when it made repetitive deep daytime dives between the surface and around $200 \mathrm{~m}$ (Fig. 10d). Distinct behaviors were also observed in Sebastián Vizcaíno Bay (SVB) with shallow dives below the MLD day and night and little time in warm surface waters (Fig. 10b), and just north of 


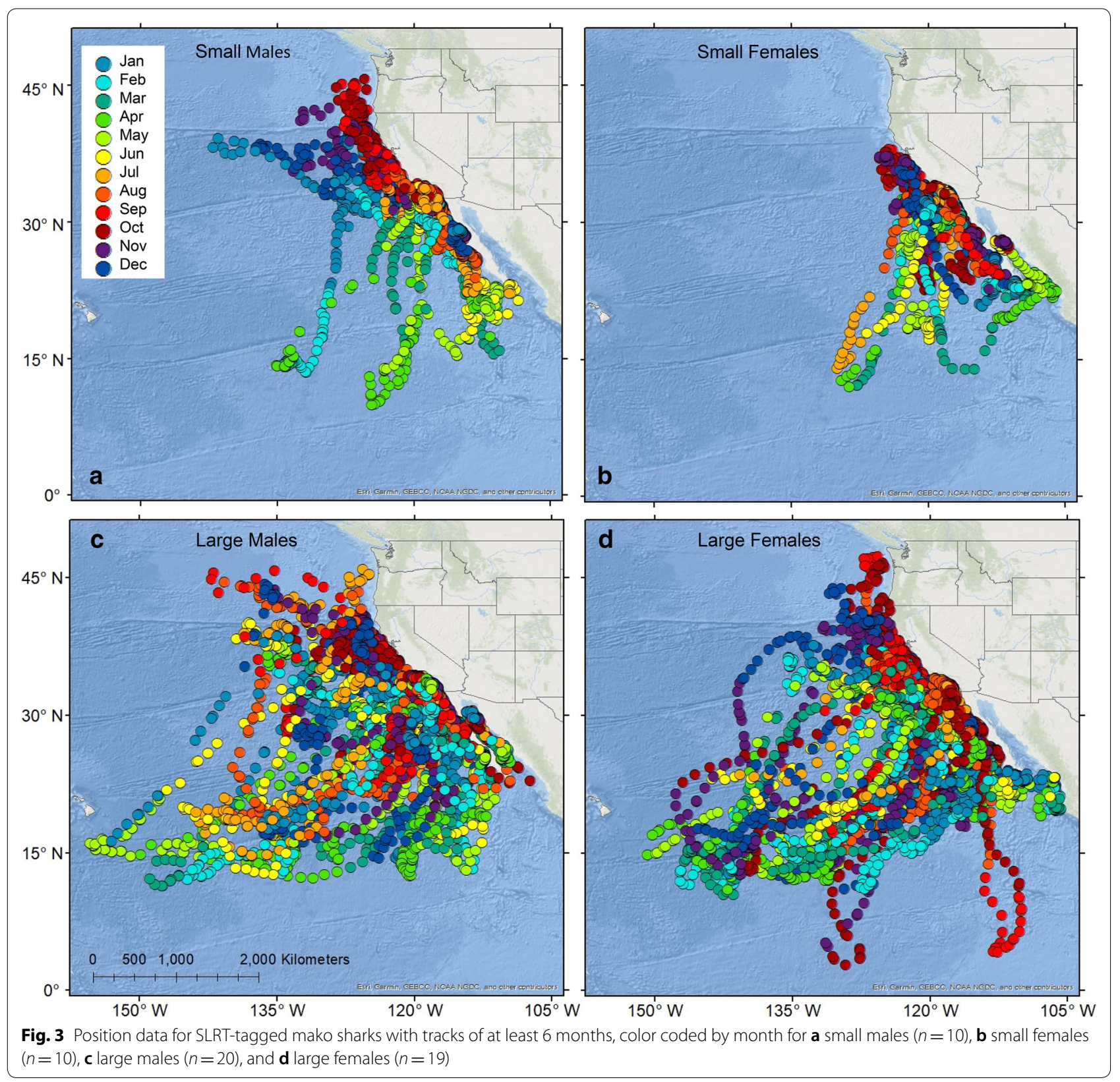

Point Conception with dives below the MLD during the day and near the surface at night (Fig. 10c).

\section{Habitat preferences and behaviors by region}

Movements, behaviors and habitat characteristics of mako sharks were examined for five regional areas: (1) the SCB; (2) the coastal region north of Point Conception; (3) the west coast of Baja California; (4) SOC; and (5) offshore. Coastal was defined as being within 200 nautical miles off the coast to approximate the US and Mexico exclusive economic zones (EEZs) which includes the approximate bounds of the California Current (Figs. 11,
12). Regions were chosen based on areas of utilization, beginning with the SCB. Environmental variables for each region were extracted from SLRT tag positions. Overall, large sharks spent $38 \%$ of detection days in the US EEZ, 21\% in the Mexican EEZ and 41\% offshore, while small sharks spent $49 \%$ of detection days in the US EEZ, $29 \%$ in the Mexican EEZ, and 22\% offshore.

\section{Southern California Bight}

All but four sharks were tagged in the SCB (Fig. 2). Three of these four moved into the SCB after tagging. Both large and small sharks had the highest occurrence in the 


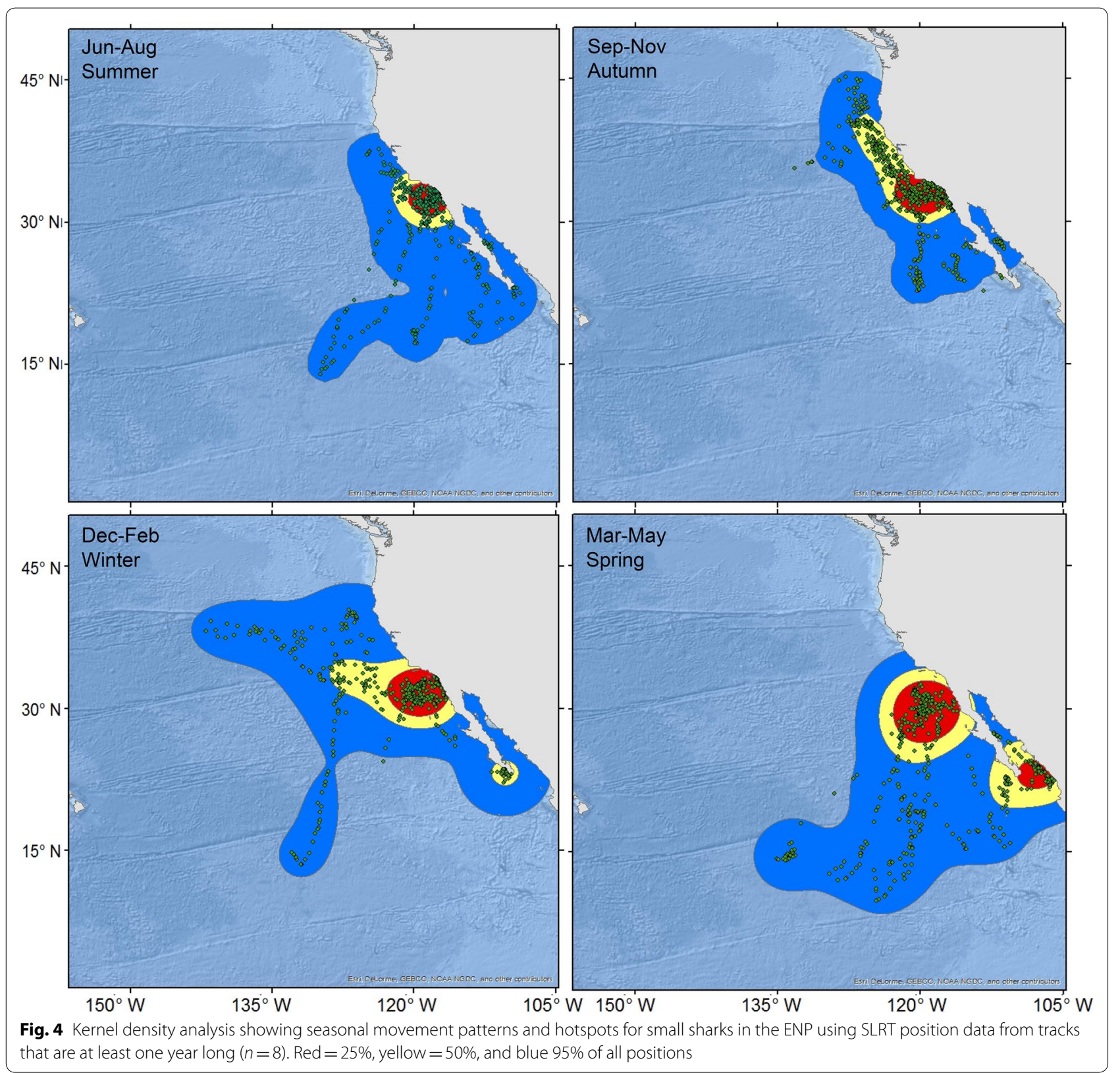

SCB between July and September (Fig. 11). Although some sharks were within the SCB in all months, in some cases they appeared to be passing through the region. For a summary of SST, Chl-a, primary productivity, and swimming depths in this region, see Table 1 and Fig. 12.

For sharks tagged in the SCB with more than 1 year of data, 27 sharks (77\%) returned to the SCB in the following year(s), arriving between mid-April and mid-September (mean return date July 2 for small sharks and June 22 for large sharks), and stayed for as long as 158 days ( $83 \pm 27$ days for small sharks and $60 \pm 46$ days for large sharks). For the eight sharks that did not return, seven were large and one was small. Of the seven large sharks, four stayed offshore or north of Point Conception and the remaining three were off the coast of Baja California from July to September. The small shark was traveling from off Baja California north toward Southern California when the tag stopped reporting in mid-July.

\section{North of Point Conception}

For sharks with more than 1 year of data, 23 traveled north of Point Conception, including 19 large sharks $(68 \%)$ and 4 small sharks (50\%). The highest percentage of 


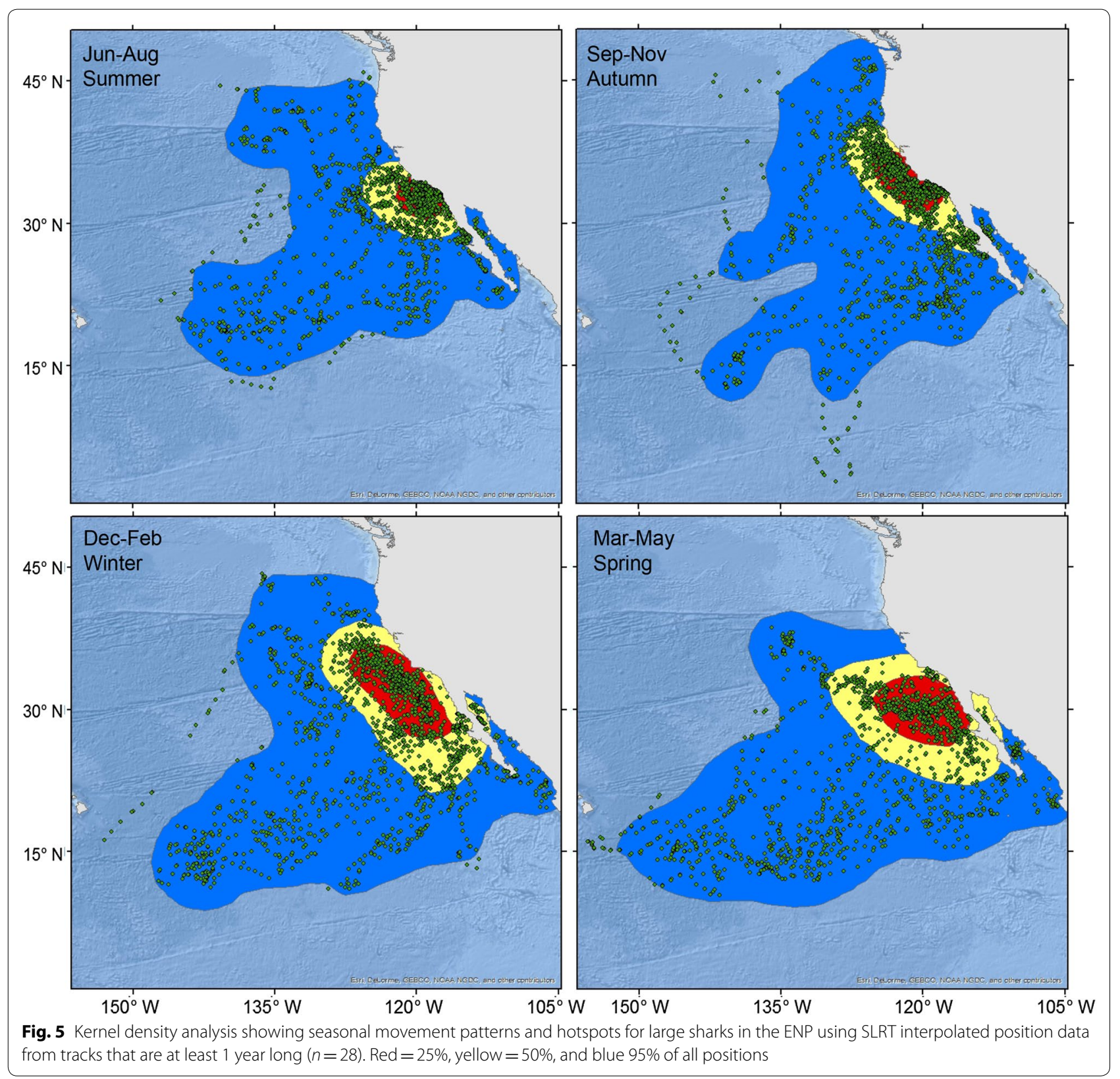

occurrence in the coastal region north of Point Conception was during August-December (Fig. 11). In general, SSTs in this region were colder and the sharks tended to spend more time at the surface with fewer deep dives. For a summary of SST, Chl-a, primary productivity and swimming depths in this region, see Table 1 and Fig. 12.

\section{West coast of Baja California}

For sharks with more than 1 year of data, 31 visited the region along the west coast of Baja California including
23 large sharks (82\%) and 4 small sharks (50\%). Tagged mako sharks were present in this region year-round with the highest occurrence in the spring (February to June) (Fig. 11). This region was relatively warmer and sharks spent time deeper in the water column. For a summary of SST, Chl-a, primary productivity and swimming depths in this region, see Table 1 and Fig. 12.

Of all SLRT-tagged sharks (including those with tracks less than a year, $n=89$ ), there were 12 sharks (119-190 cm FL) that spent more than 1 week in SVB (6 immature females, 2 immature males, and 4 mature 
a

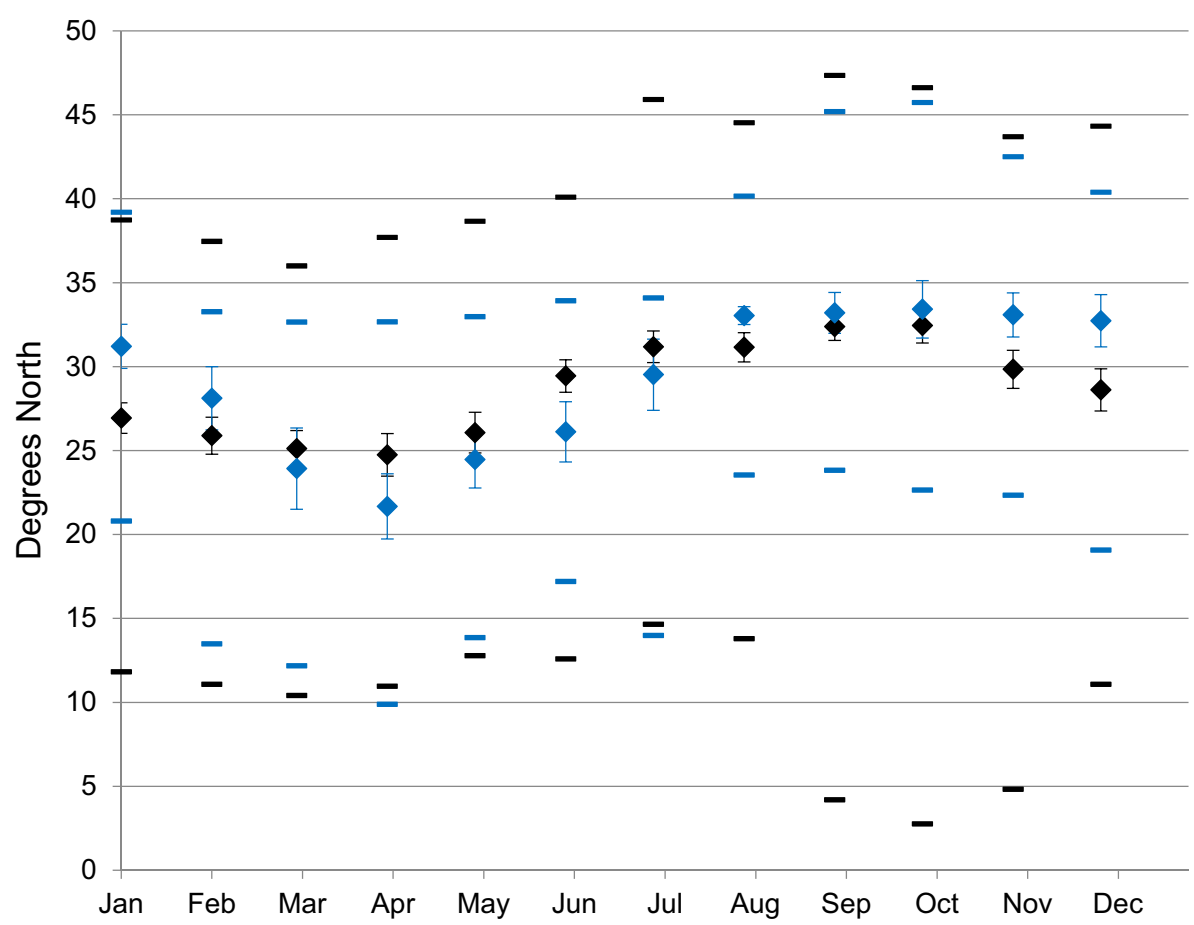

b

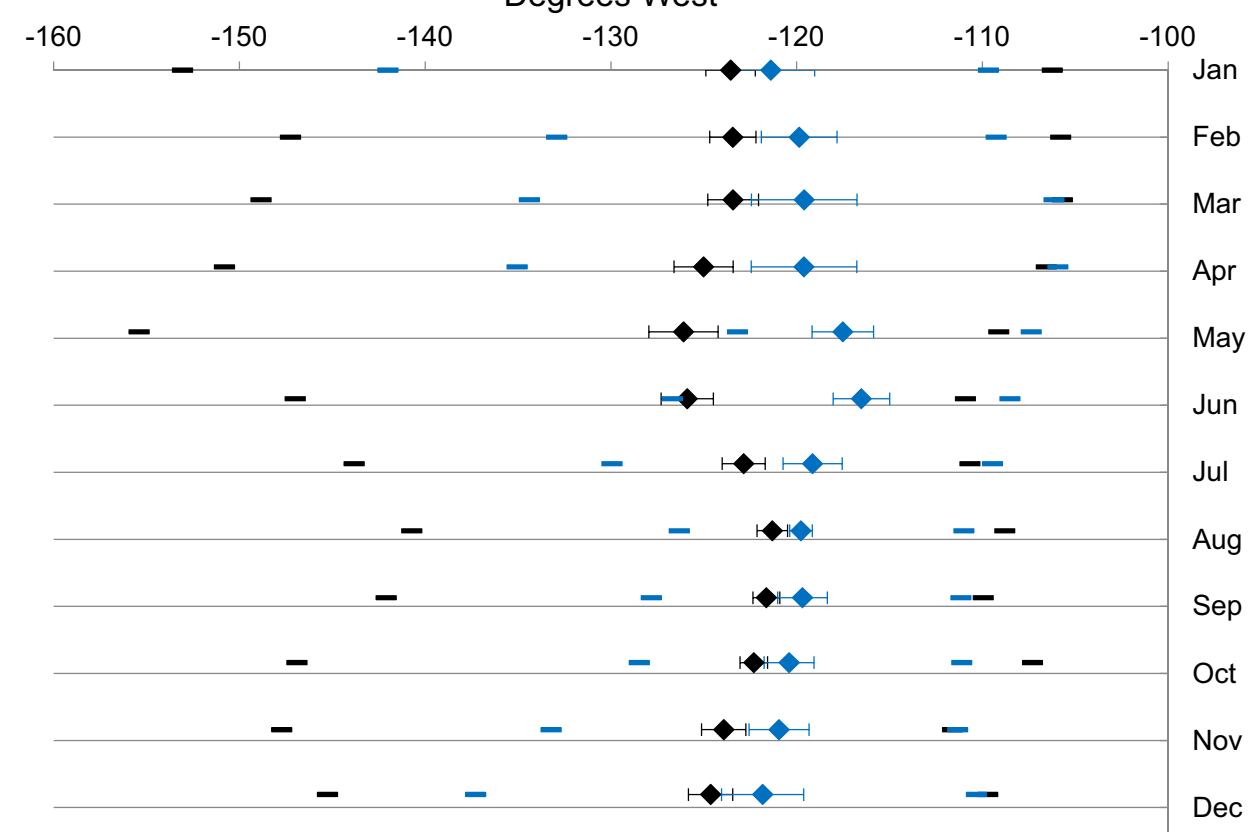

Fig. 6 Mean a latitude and $\mathbf{b}$ longitude with standard error by month for large (black, $n=28$ ) and small (blue, $n=8)$ SLRT-tagged mako sharks with tracks greater than a year. Black and blue bars show the minimum and maximum latitudes and longitudes for large and small sharks during each month 


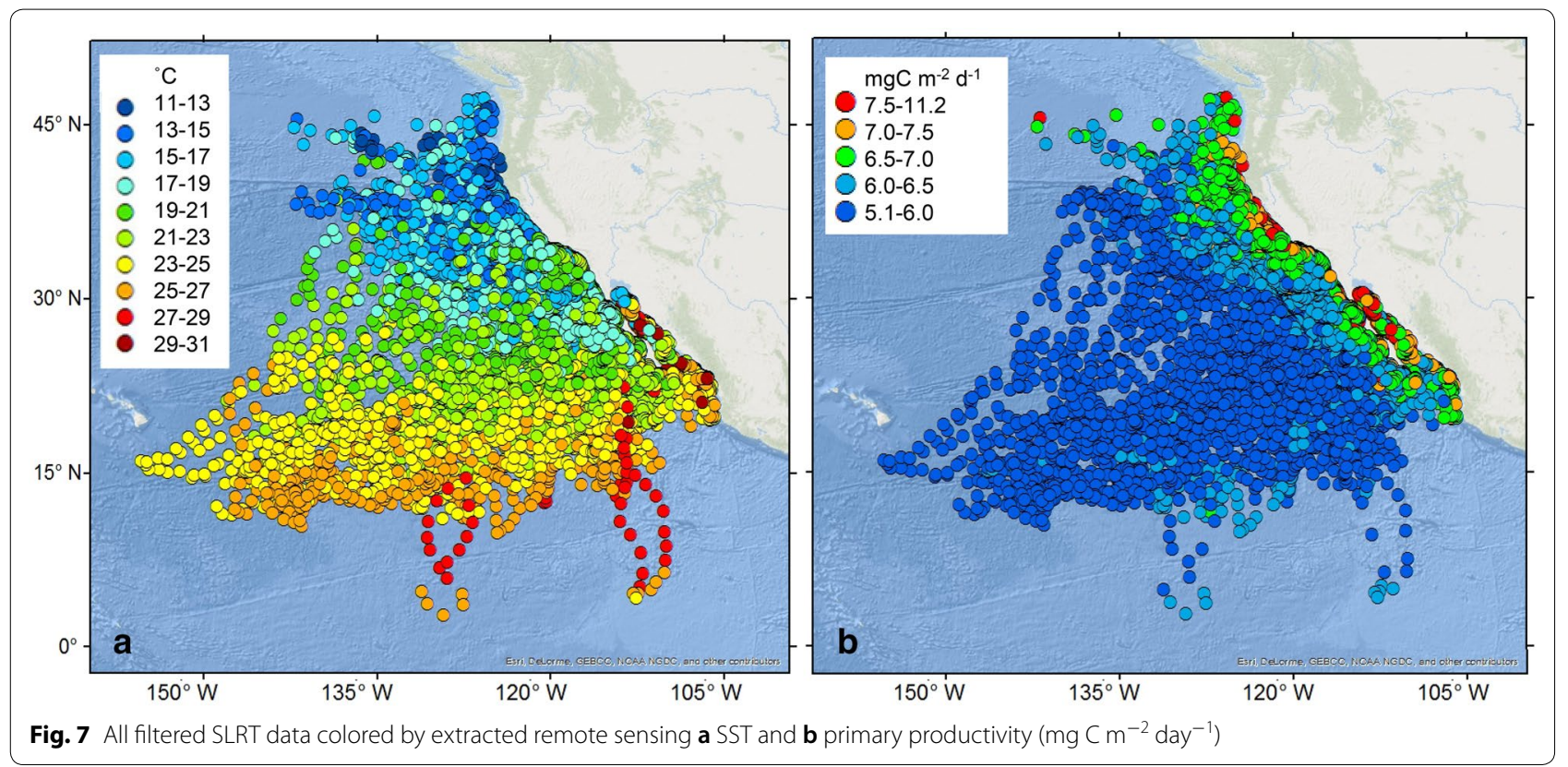

Table 1 Summary of environmental factors by region

\begin{tabular}{|c|c|c|c|c|c|}
\hline & N Pt Conc & SCB & Baja & SOC & Offshore \\
\hline $\mathrm{SST} \min \left({ }^{\circ} \mathrm{C}\right)$ & 11.3 & 11.9 & 14.1 & 14.4 & 11.3 \\
\hline SST mean $\left({ }^{\circ} \mathrm{C}\right)$ & 15.4 & 17.9 & 19.6 & 23.2 & 20.9 \\
\hline SST max $\left({ }^{\circ} \mathrm{C}\right)$ & 20.2 & 24.1 & 29.5 & 31.2 & 28.8 \\
\hline PP mean (mg C $\mathrm{m}^{-2}$ day $^{-1}$ ) & 6.9 & 6.8 & 6.5 & 7.1 & 5.8 \\
\hline Chl-a mean $\left(\mathrm{mg} \mathrm{m}^{-3}\right)$ & 0.9 & 0.6 & 0.4 & 1.2 & 0.1 \\
\hline Max depth (m) & 350 & 528 & $\sim 700$ & NA & 680 \\
\hline \% Time at surface $(<5 \mathrm{~m})$ & 50.2 & 46.7 & 36.7 & NA & 30.3 \\
\hline$\%$ Time $<50$ m & 94.2 & 92.1 & 84.7 & NA & 70.4 \\
\hline \% Time > 150 m & 0.9 & 1.6 & 1.5 & NA & 6.1 \\
\hline
\end{tabular}

Summary of SST (sea surface temperature), PP (primary productivity), Chl-a (Chlorophyll $a$ ), maximum depth, percent time at the surface, percent time $<50 \mathrm{~m}$, and percent time $>150 \mathrm{~m}$ for each region (SCB Southern California Bight, N Pt Conc north of Point Conception, Baja Baja California Mexico, SOC Sea of Cortez, and offshore)

males). These sharks were present between mid-July and early February and stayed for between 10 and 131 days ( $44 \pm 29$ days). One of the large sharks (female, $173 \mathrm{~cm}$ $\mathrm{FL}$ ) did not return to SCB in the year following tagging, but traveled to SVB and remained from 1 July through 9 September. There was not a significant difference between time spent in this area for small or large sharks (Mann-Whitney rank-sum test, $U=15, n_{1}=8, n_{2}=4$, $p>0.05$ ) or for male or female sharks (Mann-Whitney rank-sum test, $U=9, n_{1}=n_{2}=6, p>0.05$ ), while in SVB, sharks spent a mean of $30.8 \%$ of time at the surface $(<5 \mathrm{~m})$ and $87.6 \%$ of time in the top $50 \mathrm{~m}$ with $0.2 \%$ time below $150 \mathrm{~m}$ (see Fig. 10b for an example).

\section{Sea of Cortez}

Three SLRT-tagged sharks with tracks ranging from 4 to 13 months traveled into the SOC with at least one shark occurring there during each month. Shark 04-13PS, tagged off Baja, moved into this region in March and was still there in November when the tag stopped reporting (poor location data July through September). Shark 07-4PS was tagged in July in the SCB and traveled into the SOC in August and was still there in November when the tag stopped reporting. The third shark (09-2S) was tagged in August in the SCB and moved into the SOC in October and remained there until the following August when it moved back along the west coast of Baja to SVB. The shark then moved into the SOC again in October and remained there for the next 16 months at which point the tag stopped transmitting. Sharks encountered a broad range of SSTs in the SOC as a consequence of visiting there in the winter and summer (Table 1). SSTs were significantly lower from December to April $\left(21.0 \pm 2.9{ }^{\circ} \mathrm{C}\right)$ than from May to November $\left(25.7 \pm 2.5{ }^{\circ} \mathrm{C}\right)$ ( $t$ test, $t=16.5, d f=400, p<0.0001)$. Chl-a did not differ significantly between December to April and May-November ( $t$ test, $t=1.1, d f=400, p=0.27$ ). PSAT data were not available from sharks in this region. SLRT tags reported poorly during the summer months, indicating that the sharks were likely spending less time near the surface as SST increased.

\section{Offshore}

For sharks with more than 1 year of data $(n=38)$, all but two sharks utilized the offshore region. The two 


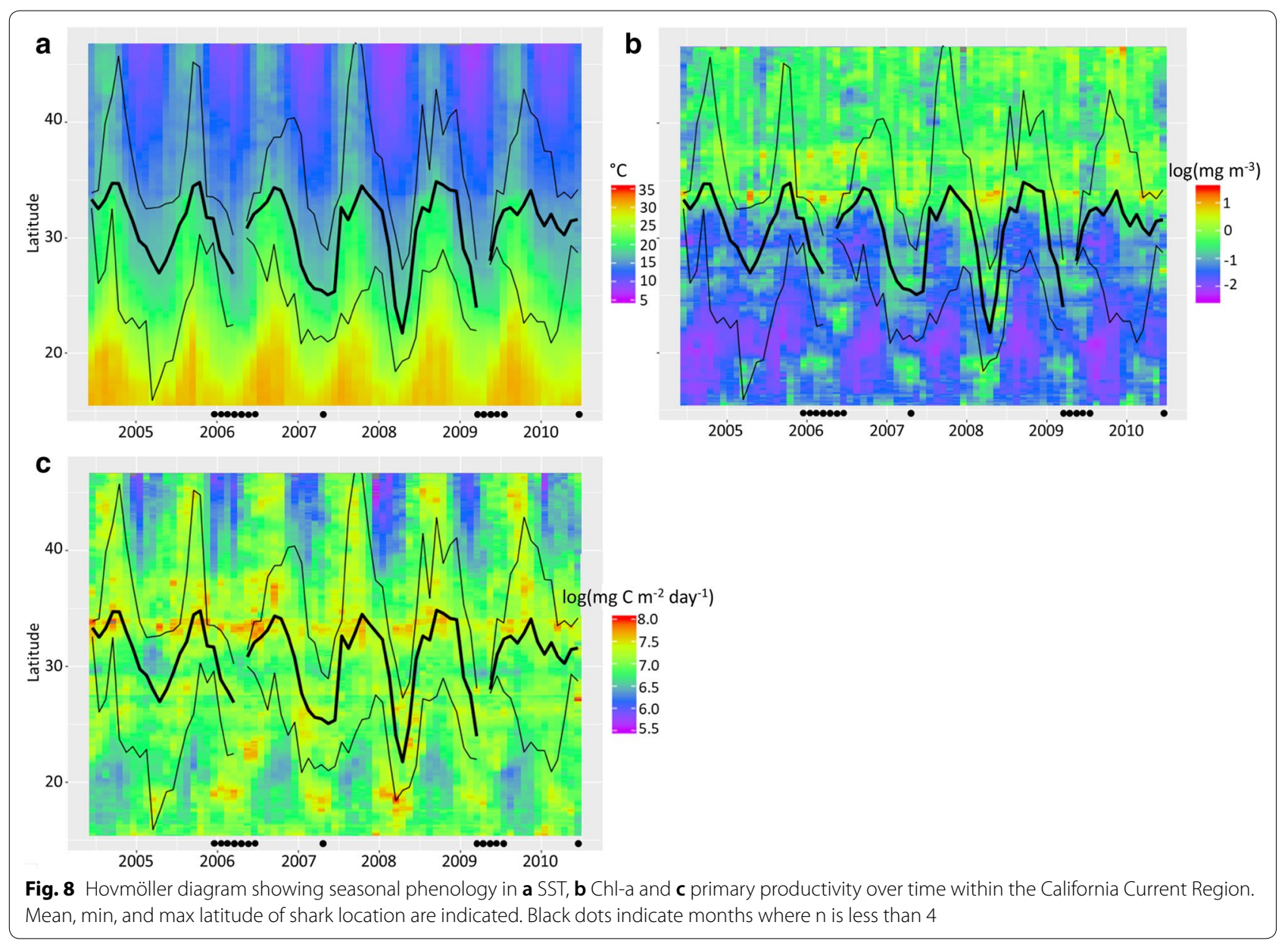

sharks that did not travel offshore (one large and one small shark) both spent significant time in the SOC (8-16 months). Mako sharks were offshore in all months, with the highest occurrence from December through June (Fig. 11b). For a summary of SST, Chl-a, primary productivity and swimming depths in this region, see Table 1 and Fig. 12. SSTs were cooler in the northern portion of the offshore region, $15.9 \pm 1.8^{\circ} \mathrm{C}$ for the NPTZ and area north of Point Conception and $21.5 \pm 3.3{ }^{\circ} \mathrm{C}$ for the offshore area south of Point Conception toward the North Equatorial Current. Movements varied greatly among individuals, and although there was no common offshore destination, there were some notable patterns. Multiyear tracks indicated similar patterns in offshore movements over consecutive years for individual sharks. For example, shark 09-1S, a 205-cm FL immature female, traveled to the same offshore region in three consecutive years, from mid-December to mid-February the first year, mid-February to mid-March the second year, and midMarch to mid-April the third year (Fig. 13). In addition, four of the sharks large enough to be mature, including three males $\geq 223 \mathrm{~cm}$ FL (08-8PS, 09-3S, and 09-12PS) and one female $\geq 280 \mathrm{~cm}$ FL (14-1S), moved directly from the SCB region offshore to the southwest with no north-south movements along the coast (Fig. 14). The two mature sharks with tracks greater than 1 year both moved offshore in the fall and returned to the SCB by the following summer.

\section{Regional differences in habitat}

PSAT data showed a shift in vertical habitat use between regions. Mako depth distributions from the SCB and north of Point Conception were similar although overall temperatures experienced in the north were cooler with the highest percent of time spent at $14-16{ }^{\circ} \mathrm{C}$ in comparison with $16-18{ }^{\circ} \mathrm{C}$ in the SCB (Fig. 12). Warmest temperatures and deepest vertical movements were apparent in the offshore region where overall the highest percent of time was spent between 22 and $24{ }^{\circ} \mathrm{C}$ and where the least amount of time of all regions was spent near the surface with progressively more time (compared with other regions) below $50 \mathrm{~m}$ (Fig. 12). Intermediate between offshore and the two US coastal regions was the Baja Peninsula region where 


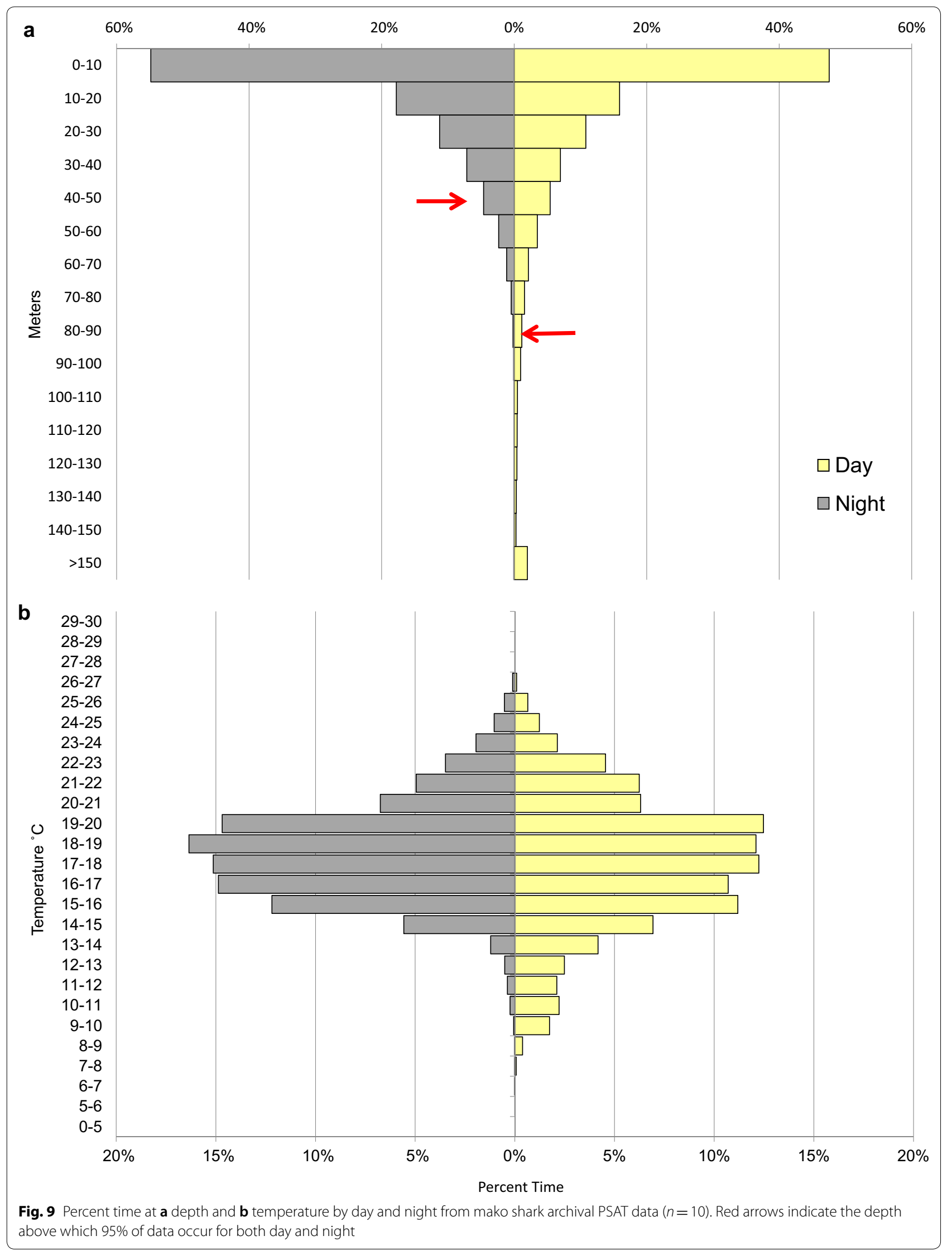




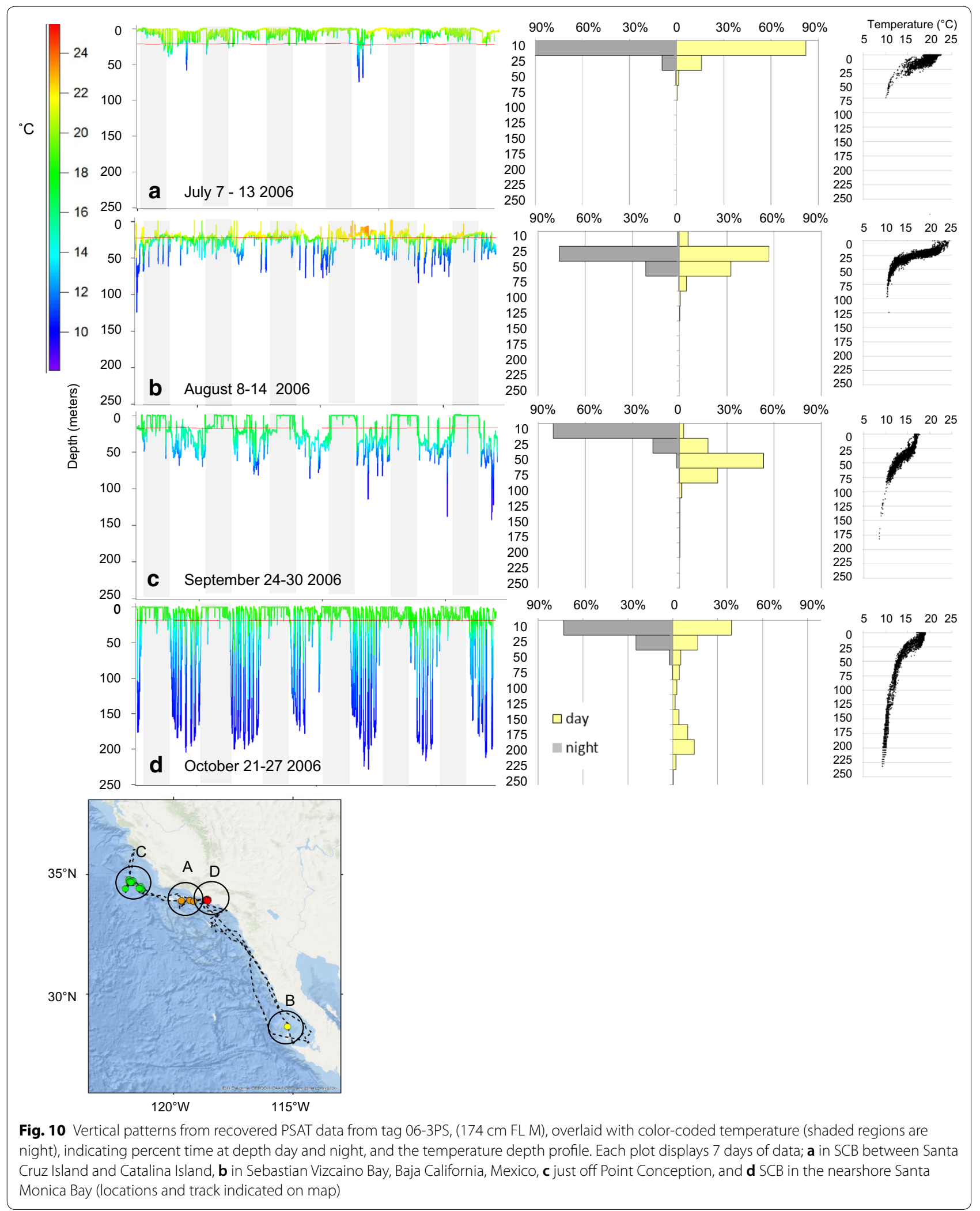




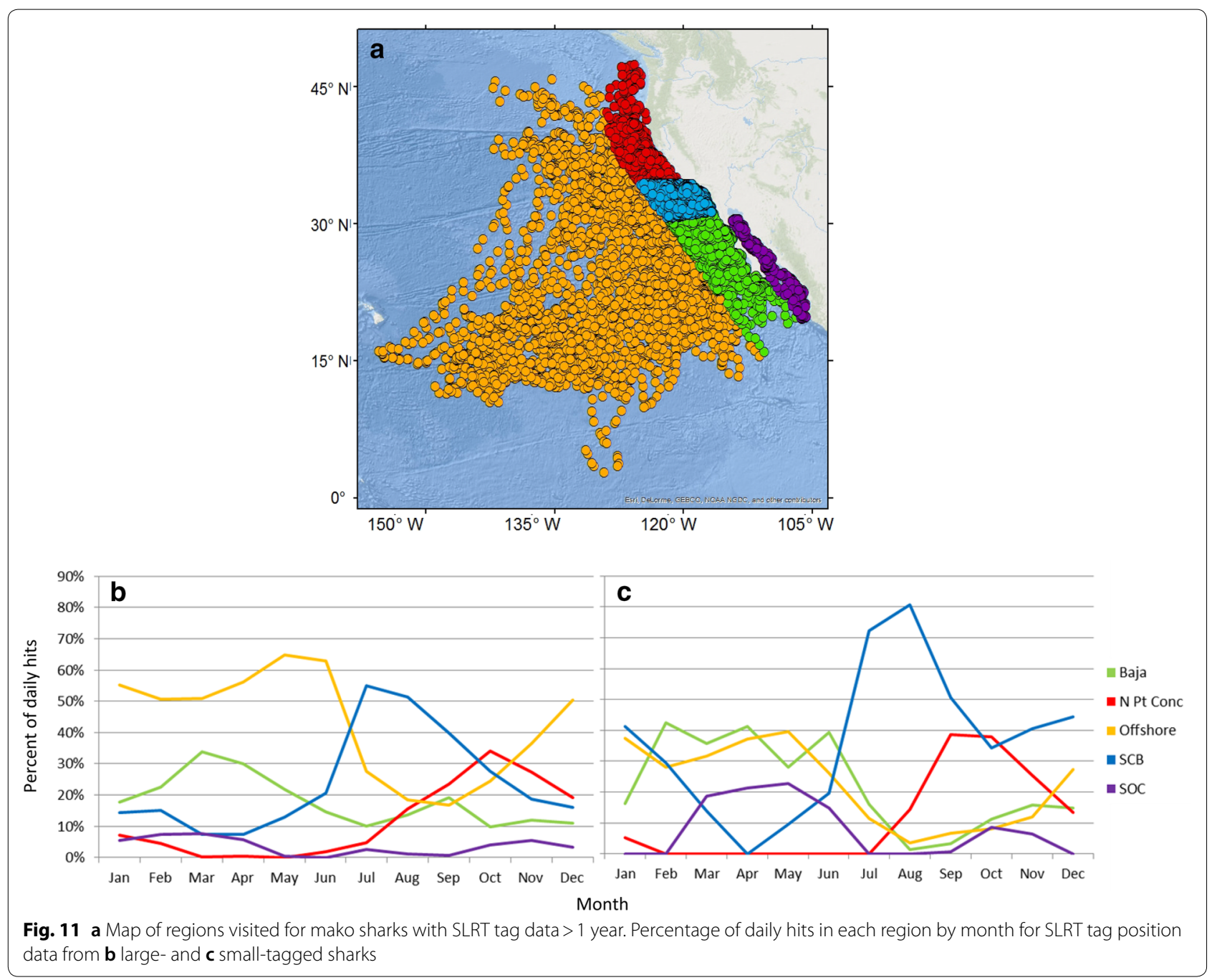

the highest percent of time was spent between 18 and $20{ }^{\circ} \mathrm{C}$. Additional insight into a shift in vertical habitat use offshore comes from one of the large double-tagged sharks (08-8PS, $223 \mathrm{~cm} \mathrm{FL)} \mathrm{with} 241$ days of PSAT data and 248 days of SLRT data. This shark made two roundtrip movements offshore (Figs. 14, 15). As the shark moved offshore, time spent in the top $50 \mathrm{~m}$ decreased from 95.5 to $60 \%$.

\section{Discussion}

This study presents electronic tagging data of 105 shortfin makos in the ENP over a 13-year time period, depicting the horizontal and vertical movements of both sexes across a range of sizes with tracks lasting as long as 34 months. This has resulted in a large dataset that provides insight into mako habitat use and migrations and the factors that influence their behavior and offers the first opportunity to examine the effects of size on distribution and movement patterns of mako sharks in the ENP. Some of the key findings include the discovery of a high degree of variability between individuals in their vertical and horizontal movements, a strong influence of body size and season on mako shark movements, and the repetitive use of certain areas by individuals. These results expand our understanding of the distribution of mako sharks in the ENP and the importance of oceanographic features beyond the California Current, including the Subtropical Gyre, the NPTZ, the North Equatorial Current and the SOC.

\section{Horizontal movements \\ Regional/seasonal}

Horizontal distribution of tagged makos in this study covered a broad range of the ENP including coastal and offshore habitats. The ability to make large-scale migrations has been linked to endothermy and expanded 

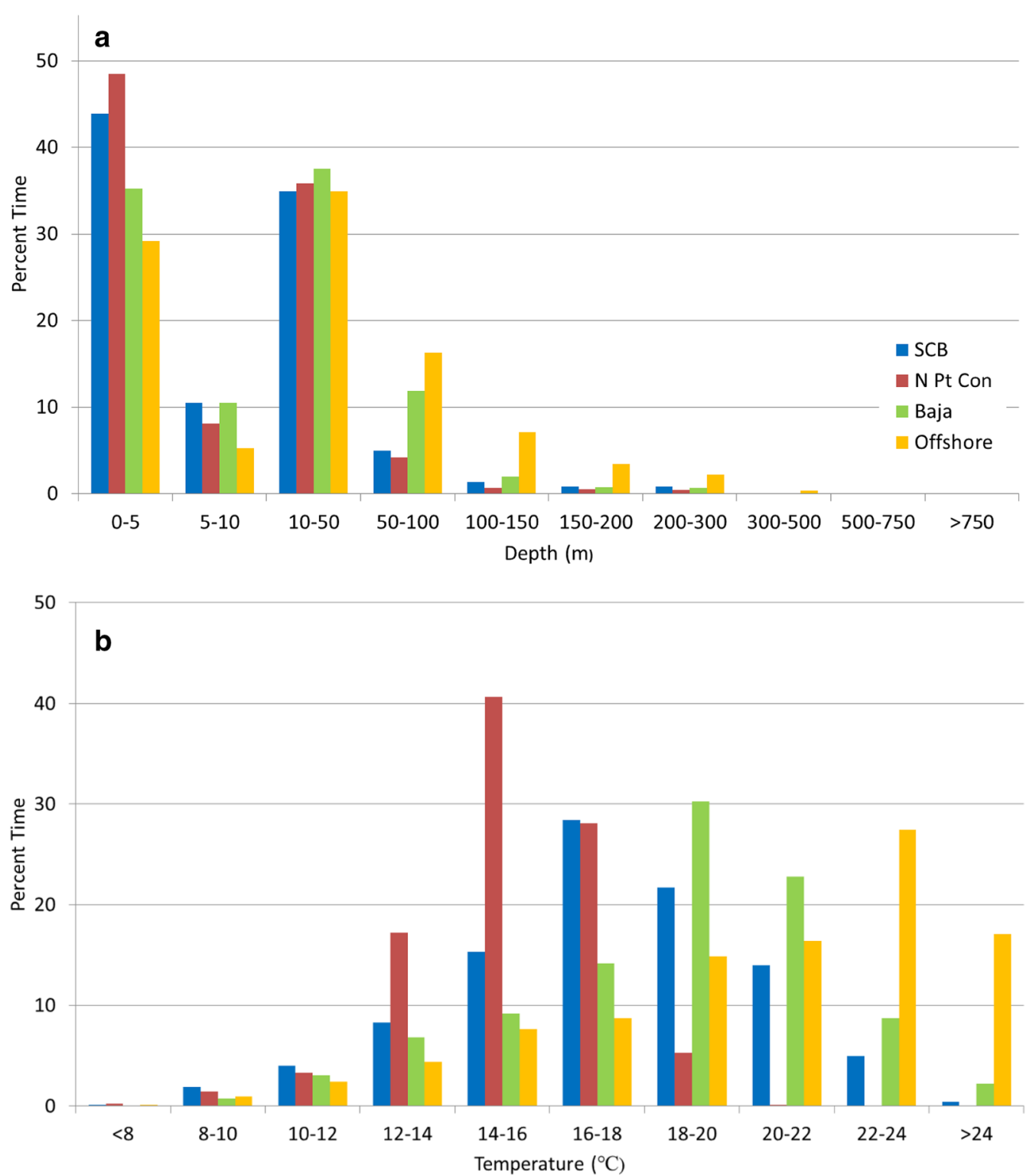

Fig. 12 Graphs showing $\mathbf{a}$ time at depth and $\mathbf{b}$ time at temperature for PSAT tag data > 3 mo within each region. Note that no PSAT data were available from the Sea of Cortez

thermal habitats and higher cruising speed [39]. The preferred habitat includes the entire extent of the California Current region off both the US and Mexican coast, as well as offshore spanning from tropical to temperate waters.

Makos demonstrated a seasonal presence in the SCB in late spring through early fall returning in consecutive years, confirming the importance of this region. Although there is a potential for tagging bias, as nearly all tags were deployed in the SCB, $77 \%$ of sharks in this study with more than 1 year of data returned to the SCB between April and September the years(s) following tagging and stayed for as long as 158 days, demonstrating the importance of the SCB in the summer months. This confirmation of the importance of the SCB is consistent with previous tagging studies as well as catch data which identify the SCB both as a nursery area for YOY and juveniles and a foraging ground for subadults and adults $[7,8,27]$. This region is also a nursery area for other pelagic sharks including white and common thresher sharks (Alopias vulpinus) [40-42] and bears similarity to the Great Australian Bight where the shelf and slope 


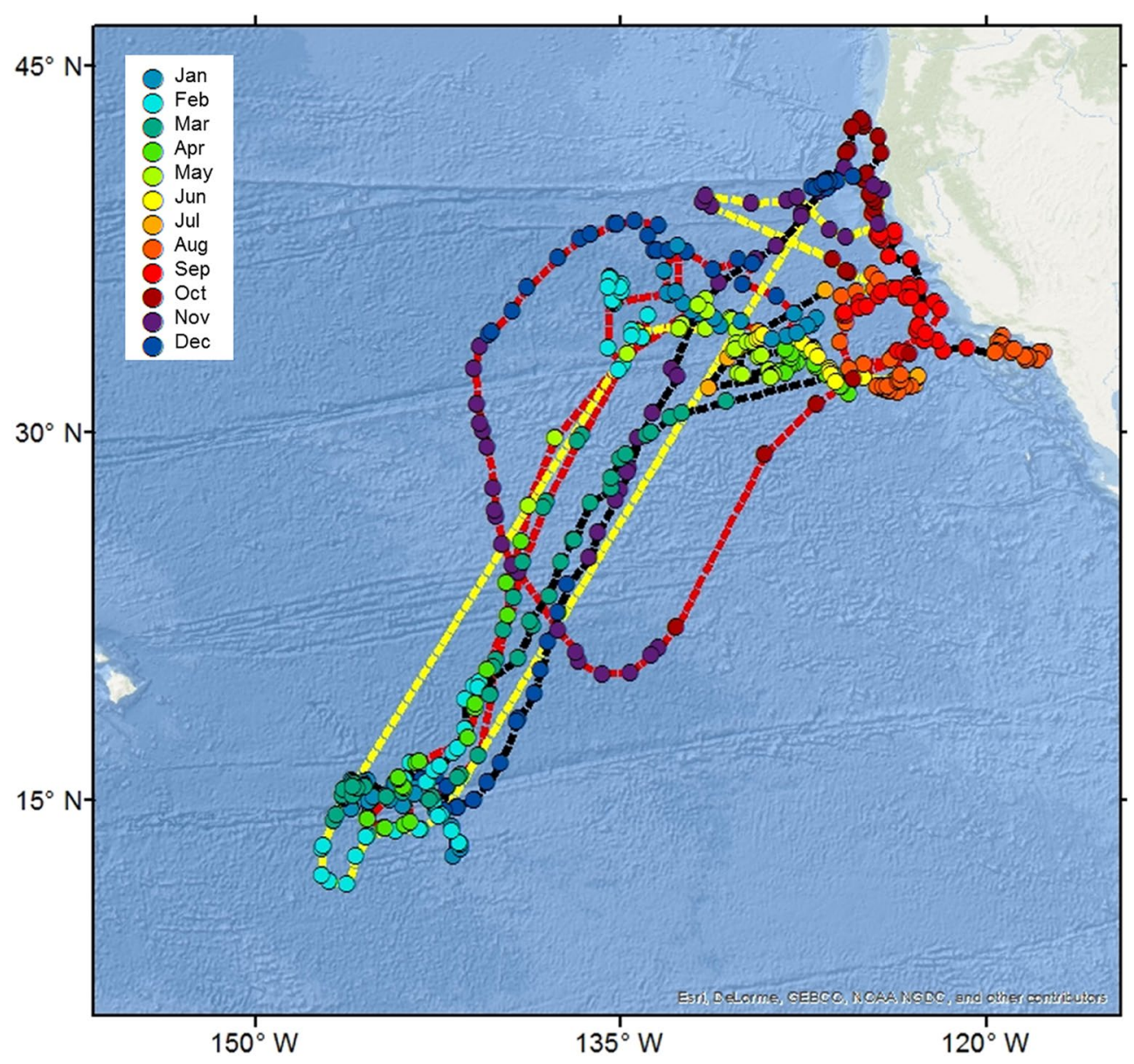

Fig. 13 Tracking data for shark 09-1S, a 205-cm FL female, shows similar offshore tracks over three consecutive years. Dashed line indicates the year of tracking with black $=$ first year, yellow $=$ second year, and red $=$ third year

are important habitats for juvenile makos [2]. The SCB has a shallow continental shelf, offshore islands, and seamounts, which likely provide some refuge from predation for YOY and juveniles [43]. The region is also highly productive and home to a range of prey for mako sharks across size classes, from squid and fish, to marine mammals [14]. Movement into productive, coastal summer foraging grounds is also observed for mako sharks in the Atlantic and South Pacific $[2,4,5]$. In addition to mako sharks, the SCB is also a summer foraging ground for a broad range of highly migratory species including white sharks, common thresher sharks, blue sharks (Prionace glauca), billfish, marine mammals, turtles, and tuna [34, 44, 45].

While the SCB was important across individuals and size classes, there was no consistent movement pattern for the temporal timing of migrations away from the SCB. In the late summer and autumn, sharks either moved to the north, south, or offshore. Timing of movements to the north corresponded to a seasonal phenology of increased SST and a period of higher productivity in the northern California Current region associated with an increase in seasonal upwelling that occurs in September through October [44, 46, 47]. The movement of sharks to the region north of Point Conception off the coasts of California, Oregon and Washington also corresponded with optimal monthly habitat predictions for sardine, which are found off Oregon and Washington from June through November and move south of Central California from December through May [48]. Mako sharks that utilized the northern region then either dispersed offshore or moved into Mexican waters during the winter when temperatures to the north drop, coastal upwelling decreases and productivity off the coast of Baja California peaks [47] (Fig. 8). This north-south migration pattern within the California current region is similar to that of other marine animals such as tunas, salmon 


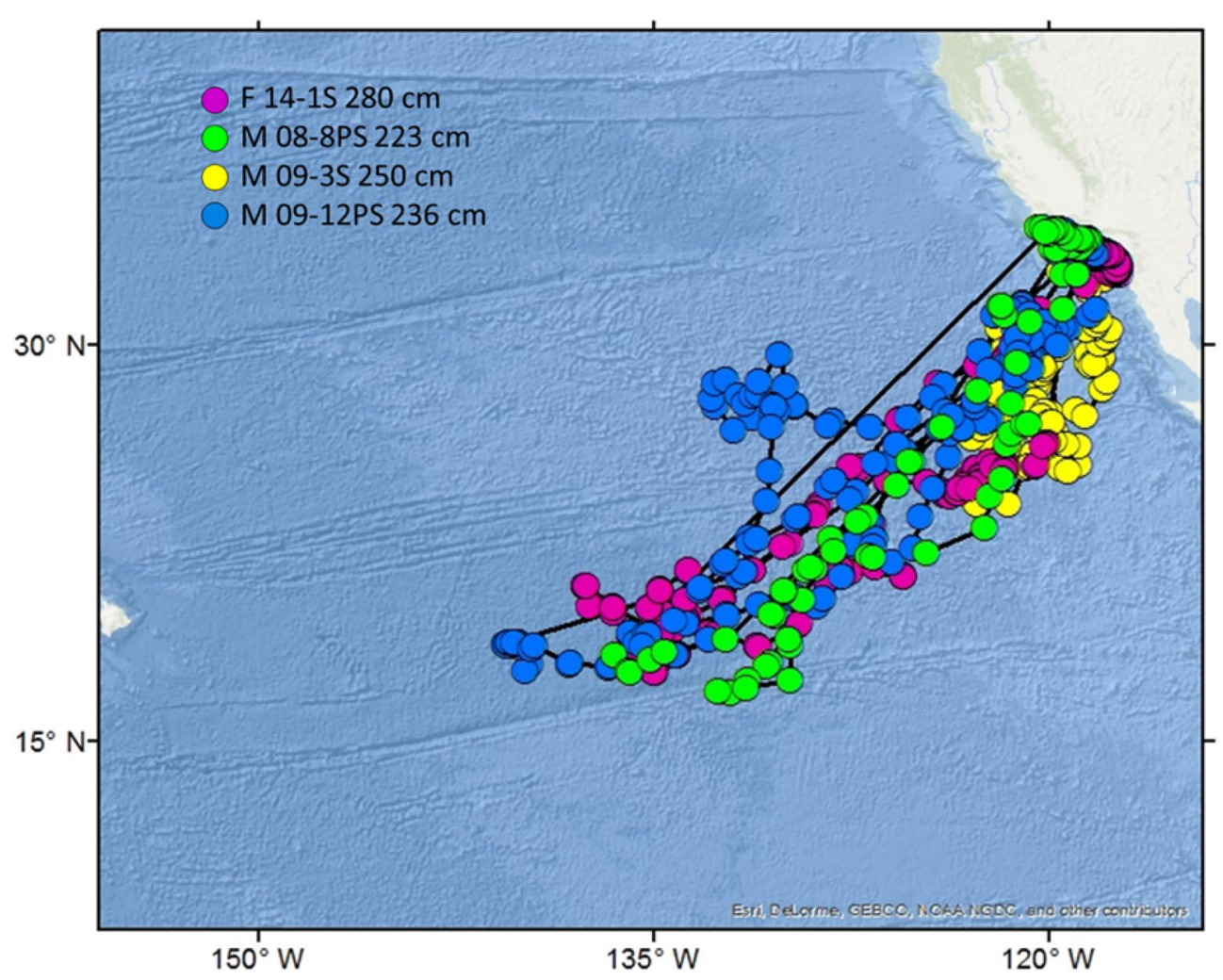

Fig. 14 Movements of four large mako sharks offshore, males $\geq 223 \mathrm{~cm} \mathrm{FL} \mathrm{(} n=3 ; 248-498$ days) and female $\geq 280 \mathrm{~cm}$ FL ( $n=1 ; 456$ days)

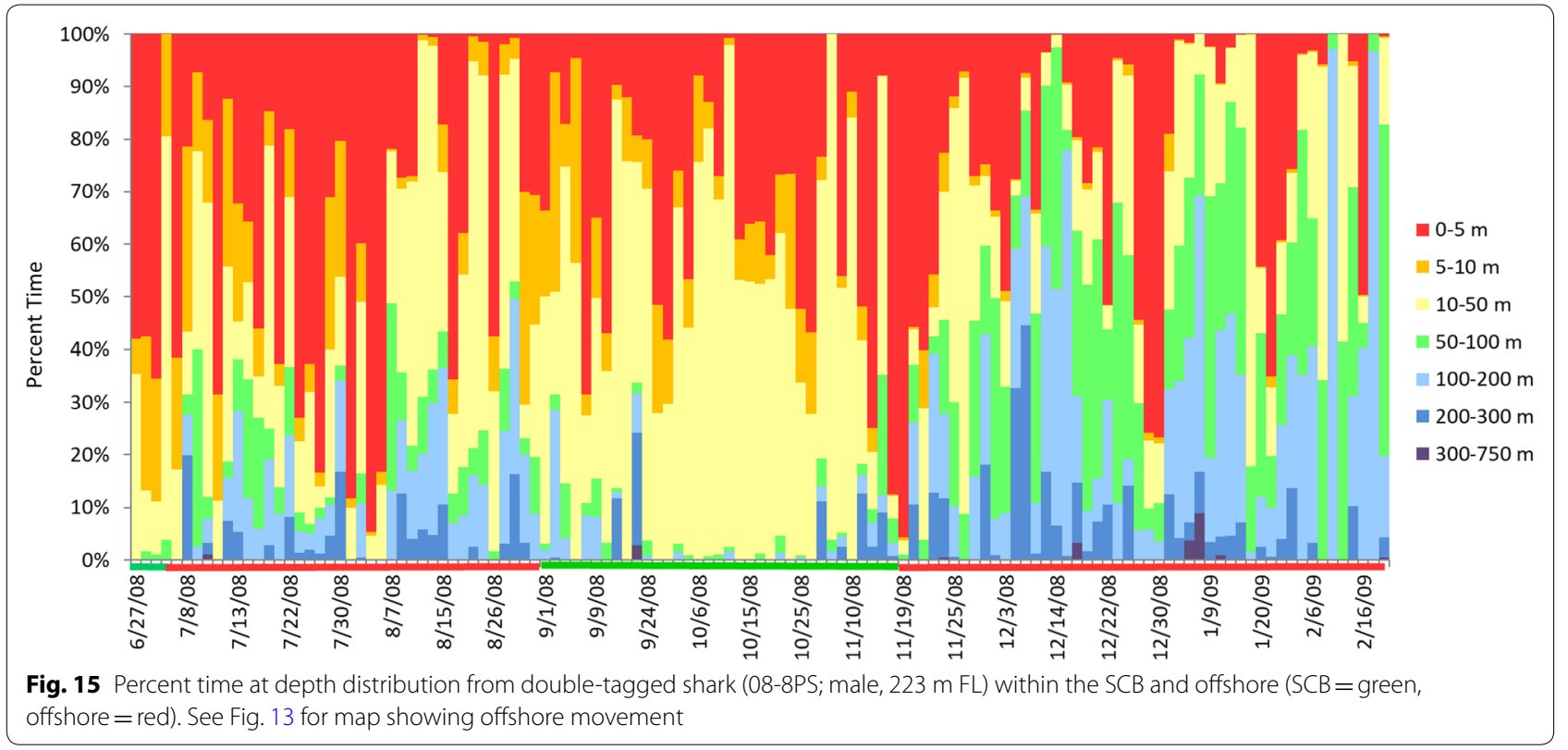

sharks (Lamna ditropis), and blue whales (Balaenoptera musculus) [34, 44].
Sharks traveling into the southern California Current region off of Baja California, Mexico, arrived most often either in late summer from the SCB, or late fall/early 
winter after traveling north of Point Conception. Within this region, some sharks spent more time in SVB and the SOC. This included one shark (shark 09-2S; male, $174 \mathrm{~m}$ $\mathrm{FL}$ ) that did not return to the SCB but traveled between the SOC and the SVB. Both of these areas are known for high productivity throughout the year and support a large biomass of sardine that are found in mako stomach contents [14, 49]. In addition, the SVB has been recognized as a nursery area for white sharks $[50,51]$. The SOC is characterized by significant upwelling events in winter and early spring during which surface temperatures drop to as low as $14{ }^{\circ} \mathrm{C}$. During the summer, surface temperatures can reach $31{ }^{\circ} \mathrm{C}$ [52]. These data showed mako sharks moving into the SOC in late summer or fall and remaining there for as long as 16 months, indicating that sharks can remain in the SOC year round despite the high SST.

The greatest insight into new habitat use for mako sharks comes from the tag data revealing extensive offshore movements which occurred predominantly in the winter and spring months. Sharks either moved directly offshore from the SCB or following movement north or south within the California Current. One important offshore region was to the south near the North Equatorial Current where fisheries data are not available. All but two sharks that moved into this area ceased southward movements at around $12-20^{\circ} \mathrm{N}$ and then remained in the area for some period. This region differed from the shared offshore foraging area utilized by male white sharks, which is a large area centered around approximately $23.5^{\circ} \mathrm{N}$, $137^{\circ} \mathrm{W}[53,54]$. Why some sharks move into subtropical waters is not clear. It does not appear to be related to reproduction as both immature and mature mako sharks reached the same southerly latitudes and showed the same general seasonal pattern, indicating that it is more likely linked to foraging. While lower than in the California Current, productivity in this region is relatively high for oligotrophic offshore waters. Productivity is enhanced by the shoaling of the thermocline at the edge of the North Pacific Subtropical Gyre and the shear of the equatorial current, as is evidenced by an increase in nutrients, sea birds and marine mammals in this region [55]. In addition, this region also contains the Clarion Fracture, which has a large number of topographic features such as seamounts, hills, and channels. The edge between a region of vertical relief and the flat seafloor is likely associated with increased foraging opportunities [56]. Whether there is a barrier to movements further south is not clear. Beyond this point, temperatures increase and the oxygen minimum zone in the eastern tropical Pacific shoals dramatically, reaching $\mathrm{O}_{2}$ levels of $1.5 \mathrm{ml} / \mathrm{L}$ at $200 \mathrm{~m}$ at $\sim 12^{\circ} \mathrm{N}$ latitude [57]. Although mechanisms and cues are unclear, the movements of mako sharks are similar to offshore migration patterns for other species that seasonally utilize the California Current, including white sharks, blue sharks, salmon sharks, Pacific bluefin tuna (Thunnus orientalis), and leatherback sea turtles (Dermochelys coriacea) [33].

The offshore movements in the northern region occurred near the boundary of the subarctic gyre and subtropical gyre in the NPTZ. In this region cool, high chlorophyll surface water sinks beneath warm, low chlorophyll water and overall productivity is enhanced [58]. Other species such as loggerhead turtles (Caretta caretta), albacore tuna (Thunnus alalunga), female elephant seals (Mirounga angustirostris), salmon sharks, swordfish (Xiphias gladius), and bluefin tuna have been shown to forage in, and travel along, this front [34, 58, 59]. Limited catch data are available for this region although mako sharks are caught in longline fisheries targeting the NPTZ farther to the west [60].

Although there was no common offshore destination across all tags, in longer tracks individuals returned to the same general offshore destination in successive years. This repeat migration behavior has been shown for other sharks such as tiger sharks (Galeocerdo cuvier) in the Atlantic Ocean [61] and salmon sharks in the Pacific Ocean [62] but has not been reported in studies for mako sharks, most likely due to the paucity of multi-year tracking data. This behavior differs from the offshore movements of white sharks for which mature males show repeat annual migrations that end in a specific common offshore area [54]. The ability to remember the location of foraging grounds and return to them is termed the "learned migration goal" hypothesis and has been suggested for leatherback sea turtles [63]. Such a mechanism could also be used by mako sharks to return to a location that was previously found to be favorable and could act to reduce competition for foraging in offshore habits where resources are more disperse.

Since seasonal patterns were evident, environmental factors were examined in relation to horizontal movements to assess motivations. A key factor linked to habitat use across many marine species is SST. In the California Current, sharks occurred primarily in SST ranging from 15 to $25^{\circ} \mathrm{C}$ which is similar to reports from previous fisheries-dependent studies that suggested that the mako shark distribution in the Atlantic was tied to a preferred SST range of $17-22{ }^{\circ} \mathrm{C}[64,65]$. Over all regions, however, mako sharks in this study occurred across SST from $\sim 11$ to $31{ }^{\circ} \mathrm{C}$ indicating a much broader thermal tolerance and that overall movement is not necessarily limited by SST. Other recent electronic tagging studies in the western North Atlantic and South Pacific have also shown mako movements in areas where SST ranges from 8 to $31{ }^{\circ} \mathrm{C}[2,3,5]$. The general movement 
pattern of tagged mako sharks does appear to correspond with regional changes in productivity which likely coincide with prey distribution (Fig. 8) and SST does not appear to be as much of a limiting factor as previously suggested. Interpretation of environmental data is complicated by the fact that algorithms used to calculate primary productivity include temperature.

\section{Sex and size}

In addition to seasonal shifts in environmental factors, sex has been shown to influence the movements and distributions of some shark species [54, 66-68]. In general, males and females in this study used a similar geographic range with minimal north-south differences (Fig. 3). The exception was the movement of two large females that traveled south into the region of the Equatorial Countercurrent and five males that traveled up to $1400 \mathrm{~km}$ (to $142^{\circ} \mathrm{W}$ ) off the coast of northern Oregon in the area of the NPTZ. Our results do not show a large degree of sexual segregation for mako sharks in the ENP; however, studies with large sample sizes based on fisheries data have shown segregation by sex in the North and South Pacific [60, 69].

Our data suggest size had a more obvious effect on the large-scale movements of mako sharks than sex. Kinney et al. [38], using a Bayesian analysis on a subset of these data, found size to be a stronger signal for spatial separation than sex, although their study was not meant to address the ecological significance of mako movement patterns. The north-south range across size classes of mako sharks in that study was similar, but larger sharks tended to make more extensive offshore movements. Larger sharks were present west of $140^{\circ} \mathrm{W}$ in all months and spent more time offshore and less time in the California Current. Only one small male (shark 10-4S, $147 \mathrm{~m}$ FL) moved west of $140^{\circ} \mathrm{W}$ (Fig. 3). While the range may be influenced by the smaller sample size and shorter track durations for small sharks, examples of juvenile sharks staying close to shore have also been observed for makos in the western North Atlantic and Australia [2, 4]. This is consistent with the SCB being used as a nursery for YOY and juvenile mako sharks, although further long-term tagging studies are needed to examine mako shark YOY movements. (The smallest shark in this study was $104 \mathrm{~cm}$ FL.) Range extension may also be influenced by swimming capabilities as smaller sharks have lower absolute swimming speeds [70].

In this study, the four largest sharks, presumed to be mature (3 males 223-250 cm FL and 1 female $280 \mathrm{~cm}$ ), spent more time offshore in more oligotrophic waters and did not travel north or south within the highly productive coastal regions. Instead, they made repetitive movements between the SCB and a relatively consistent offshore region (Fig. 14). This pattern of directed onshore-offshore movements with limited coastal movements indicates a potential ontogenetic shift in behavior with maturity. This shift in movement by size has been documented for other shark species such as white sharks [71]. Since the SCB is a nursery area where newborn makos are found, mature females are likely coming to the SCB for pupping, although pupping and mating have never been directly observed. The similarity in movement between the SCB and a more focused offshore region by four mature sharks may reflect that as makos mature, they are driven less by foraging and growth and more toward reproduction. Further tagging studies of mature makos in the ENP should help reveal the potential role of these repetitive offshore migrations.

\section{Vertical habitat use}

In addition to horizontal movements, the use of PSATs allowed for the analysis of vertical habitat use. Our results indicate that mako sharks exhibit high levels of variability both within and among individuals in their vertical movement patterns with sharks using different portions of the water column. Overall, both size classes spent the majority of their time in the mixed layer and thermocline, approximately the top $50 \mathrm{~m}$, and most sharks made frequent vertical oscillatory dives that varied in depth. Sepulveda et al. [27] found that deep oscillatory dives in the SCB were frequently associated with successful feeding events. In addition to foraging, vertical movements are likely associated with thermoregulation with sharks returning to surface waters to thermally recharge $[6,27,72,73]$. It has also been suggested that sharks display oscillatory diving for navigation and that they may be referencing the earth's magnetic or gravitational fields $[8,74,75]$.

Variability was also apparent in diel patterns both within and among individuals. While in some areas sharks remained in the MLD day and night, in general sharks were deeper during daytime hours. This diel vertical behavior is similar to previous observations of mako sharks $[1,3,26]$ as well as a range of other pelagic sharks and teleosts [45, 76-79] and is typically associated with foraging in association with the deep-scattering layer. A previous study of the offshore environment in the ENP indicated that the region north of the North Equatorial Current and east of the Hawaiian Islands was a cold spot, relatively devoid of epipelagic life, but was observed to contain an abundance of mesopelagic squid species [80]. This is consistent with analyses showing a high abundance of jumbo squid in mako shark stomachs $[9,14]$. Stomachs also contained a range of epipelagic species, indicating that mako sharks are foraging throughout the 
water column and that vertical habitat use may vary by region. The diversity of prey habitat is likely a key factor in the high degree of variability observed in vertical movement patterns.

In addition to foraging, oceanography can also influence vertical movement, including temperature and oxygen concentrations at depth. In this study, as sharks moved offshore the depths of their dives increased. This coincides with an increase in SST, the depth of the deepscattering layer due to increased water clarity, and the depth of the oxygen minimum zone. In the ENP, the oxygen minimum zone is relatively close to the surface and likely constrains the vertical movements of mako sharks [9] as has been observed for other pelagic fish [45, 77, 81]. This pattern of increased depth offshore is apparent in other species in the ENP [45, 77]. More comprehensive analyses are not possible due to the limited data collected offshore. Additional insight comes from studies in the Atlantic Ocean and Gulf of Mexico. In waters with higher SST and a deep MLD, mako sharks showed a deeper depth distribution where maximum depths were $866 \mathrm{~m}$ and sharks spent up to $36 \%$ of their time deeper than $150 \mathrm{~m}$ [3] in comparison with $700 \mathrm{~m}$ and 0.5 to $4.5 \%$ in this study. In more temperate waters in the Western North Atlantic, their results are more similar to findings in this study where sharks spent less time in deeper waters at cooler SST and a shallower MLD. While Vaudo et al. [3] concluded that temperature was a main driver of vertical habitat use, there may be other factors influencing depth distributions in the Pacific especially given the pronounced nearshore shoaling of the oxygen minimum zone in the ENP.

\section{Management implications}

Although efforts to incorporate electronic tagging data into stock assessments have met challenges [82-84], these data can support fishery management. While experimental design is often the greatest limitation, electronic tagging datasets have some advantages over the traditional datasets used (catch, abundance index, and conventional tag data). Beyond the initial tagging effort, they are fisheries independent and provide a more comprehensive view of distribution in time and space. Catch and conventional tagging data are only obtained when and where there is fishing activity. For mako sharks specifically, there is a large gap in catch data in tropical waters and between the US EEZ and $140^{\circ} \mathrm{W}$ [83] where we now have a large set of electronic tagging data. Also, electronic tagging data can reveal direct connections between regions, information that is typically only inferred from catch data. Data from electronic tags can inform a range of parameters including stock structure and dynamics, gear vulnerability, and habitat preferences [34, 36, 44, 85-87].

Currently, for management purposes, mako sharks in the Pacific are divided into separate North and South Pacific stocks with genetic and tagging data supporting east-west mixing in the north and only minimal mixing in the south $[26,28,88]$. Consistent with the current stock structure hypothesis, tagged sharks in this study did not extend into the South Pacific. To the west, although movements in this study did not extend beyond the Hawaiian Islands, conventionally tagged sharks from the ENP have been recovered westward toward Japan [29]. Lack of movement west of Hawaii and the fidelity to the California Current confirm some substructure in the North Pacific as had been suggested $[60,89]$. If there is limited exchange of mako sharks across the Pacific, there is the potential for localized depletion.

A comparison of fish and fisheries distributions both geographically and vertically provides important insights into fleet and gear vulnerability [90] and has been used for a range of species to standardize CPUE [854] as well as reduce bycatch [91, 92]. For mako sharks, the deeper distribution of larger sharks appears to translate into an increased vulnerability to deep-set longline gear targeting bigeye tuna in the subtropical gyre waters to the north and east of Hawaii. The mean size of mako sharks caught in the Hawaii Longline fisheries is larger in the deep(mean hook depth $\sim 250 \mathrm{~m}$ ) versus shallow-set fishery (mean hook depth $\sim 60 \mathrm{~m}$ ) [93]. The fisheries-independent information on vertical movements helps distinguish between gear vulnerability and shifts in habitat use.

Both size classes spent more than half their time, in the US or Mexican EEZ where the Mexican longline, California, drift gillnet and recreational fishers in California catch mako sharks. Estimated landings in the US EEZ are relatively low with a mean from 2007 to 2016 of 11 $\mathrm{mt}$ from the recreational fleet and $25 \mathrm{mt}$ from the California drift gillnet fishery [21 and NMFS Observer data]. Mean landings in Mexico's EEZ are higher ( $870 \mathrm{mt}$ per year over the same period [94]) and make up a relatively large fraction of total mean North Pacific-wide landings which are estimated at $\sim 2600 \mathrm{mt}$ per year for the same period [22]. Mexican longliners typically catch juvenile size classes $[95,96]$. While both size classes occurred outside the US and Mexican EEZs, larger sharks spent more time outside the EEZs and are thus more vulnerable to high-seas fleets, both in the NPTZ where they are incidentally caught in the US shallow-set longline fishery for swordfish, as well as in the tropics. As information on additional international fleets becomes available, tracking data will provide insight into vulnerability of ENP mako sharks to these fisheries. To better resolve questions 
about stock structure and dynamics in the North Pacific, additional tracking data are needed for large females and ideally for sharks in the Central and Western Pacific.

\section{Conclusions}

These analyses are based on the largest satellite tagging dataset for shortfin mako sharks to date and provide detailed insight into the horizontal and vertical movements in the ENP. The scope of the project, with data from 105 sharks, tracks as long as 34 months spanning 13 years, and including both sexes across a range of sizes provides the opportunity to examine habitat use and migrations and factors that influence them. Some of the key findings include the discovery of a high degree of variability between individuals in their vertical and horizontal movements, a strong influence of size and season on mako shark movement, and the repetitive use of certain areas by individuals. These results expand our understanding of the distribution of mako sharks in the ENP and the importance of oceanographic features beyond the California Current, including the North Pacific Transition Zone, North Equatorial Current, and the SOC. Although mako sharks are thought to comprise a single stock throughout the North Pacific, horizontal distribution of tagged mako sharks in this study was limited to the ENP demonstrating some spatial substructure. This study provides important data that can be used to identify fishery and gear vulnerabilities and inform management.

\section{Methods}

A total of 113 mako sharks were tagged between 2002 and 2014 with several types of Argos satellite tags. All but four sharks were tagged in the SCB in the months of June-August. Two sharks were tagged off the coast of Baja California, Mexico, in October and January, and two were tagged north of Point Conception in November (Fig. 2, Additional file 1: Table S1). Sharks were tagged using pop-up satellite archival tags (PSATs; Model types: PAT2, PAT3, PAT4, MK10-PAT, and MiniPAT, Wildlife Computers, Redmond, WA) and/or near real-time satellite-linked radio-transmitting tags (SLRT tags; SPOT2, SPOT3, SPOT4 and SPOT5, Wildlife Computers, Redmond, WA) (Additional file 1: Table S1). In the years 2003-2009, 61\% of sharks were double-tagged with both a PSAT and SLRT.

The majority of sharks were captured during the NOAA Southwest Fisheries Science Center's annual juvenile shark surveys [97]. The sharks were caught using stainless-steel longline gear with "J" hooks baited with Pacific chub mackerel or Pacific sardine. Two miles of gear with 200 hooks was deployed with a mean soak time of $4 \mathrm{~h}$. Sharks were pulled onto a cradle that was either secured to the fantail of the vessel or hoisted onto the deck. The shark's eyes were covered with a soft wet cloth, the hook removed, and the gills irrigated with seawater. A DNA sample was taken from each shark, and sex and length [either total length (TL) or FL] were recorded. If only TL was measured, it was converted to FL using the following equation [29] where lengths are in $\mathrm{cm}$ :

$$
\mathrm{FL}=0.913 \times(\mathrm{TL})-0.397 .
$$

PSATs were anchored into the dorsal musculature below the first dorsal fin using a titanium or medicalgrade plastic darts. A plastic cable tie was inserted subcutaneously behind the tag insertion site and wrapped loosely around the satellite tag to reduce its movement and increase retention. SLRT tags were mounted on the dorsal fin using three nylon or stainless-steel bolts inserted through holes drilled through the fin. In most cases, a conventional tag was also inserted in the dorsal musculature below the first dorsal fin. Total time out of water was typically less than $10 \mathrm{~min}$. The two sharks tagged off Mexico were caught on a commercial longline vessel and handled using similar methods. Four of the larger sharks were tagged with a PSAT using a long tagging pole at the side of the vessel.

PSATs were programmed to record pressure (which was converted to depth), temperature, and light levels every 1 or $2 \mathrm{~min}$ and to release after durations of 2-9 months. Transmitted data in the form of time-attemperature and time-at-depth histograms, and temperature/depth profiles (PDT) were summarized for either 1-, 2-, 4-, 6- or 12-h periods. Because depth and temperature bins differed over the 13 years of this study, individual bins were combined to create new bins common to all tags. The resulting depth and temperature bins were $0-5,5-10,10-50,50-100,100-150,150-200,200-300$, $300-500,500-700$ and $700-1000 \mathrm{~m}$ and $<8,8-10,10-12$, $12-14,14-16,16-18,18-20,20-22,22-24$ and $>24{ }^{\circ} \mathrm{C}$, respectively. Data from the first day after tagging and the last day before tag detachment were excluded to reduce potential influences caused by tagging effects and ensure that only data when the tag was on the shark were used [45]. In the analyses of depth and temperature preferences, data from tags recording more than 3 months were used. In most cases, maximum depth and minimum temperature were determined using the PDT data. When maximum depth and minimum temperature were determined from binned data, the depth was recorded as the minimum depth for the deepest bin and temperature as the maximum temperature for the coldest bin.

For sharks that were tagged with both a PSAT and SLRT, data from both tags were combined and the higher accuracy location data from SLRT tags were used when 
available. In the absence of double-tag data, location data from PSATs were derived from light data using Wildlife Computers geolocation processing software GPE3 [98] for MK10-PAT tags, and with UKFSST [99] for PAT2, PAT3 and PAT4 tags. GPE3 implements a gridded hidden Markov model based on the methods of Pedersen et al. [100] and Basson et al. [101] using dawn and dusk light readings, surface temperature, and maximum depth as observational data, and a random walk movement model, to estimate likelihood profiles across a state space of $0.25 \times 0.25$ degree grids [Wildlife Computers, pers comm]. These types of models have been shown to produce position estimates from archival tag data with rootmean-square-error (RMSE) values of less than 0.52 and 2.4 degrees in longitude and latitude, respectively, when compared to known positions. UKFSST uses approximate longitude and latitude estimates derived from time of noon and day length based on light threshold algorithms, and SST, along with a random walk movement model in an unscented Kalman filter [99]. Lam et al. [99] found that RMSEs in UKFSST estimates of latitude and longitude for a mako shark double-tagged with a PSAT and SLRT were 0.5 and 1.2 degrees, respectively.

Archived records were obtained from recovered PSATs that provided high-resolution datasets of ambient temperature, depth, and relative light level. Tags were recovered from recaptured sharks, on beaches or using a vessel and a signal direction finder to triangulate the position of the free-floating PSAT tag. To compare nighttime and daytime activity, only archival data from recovered PSATs were used. In the transmitted data, due to the range in histogram bin intervals over the years, day- and nighttime bins were not consistent. Determination of day, night, and crepuscular periods was assigned using AstroCalc4R [102], which calculates solar zenith angles, time at sunrise, local noon, and sunset using a given location. Crepuscular periods included nautical twilight and were defined as $25 \mathrm{~min}$ before sunset and $75 \mathrm{~min}$ after, and $75 \mathrm{~min}$ before sunrise and $25 \mathrm{~min}$ after and were excluded from analyses.

SLRT tags were programmed to transmit from 200 to 500 transmissions every day, every other day, or every third day (Additional file 1: Table S1). SLRT data were filtered first by removing obviously erroneous data that showed locations well off the tracks, then by selecting a daily position with the highest location class. These daily filtered points were used to calculate distance traveled, rate of movements between points, and home range used for kernel analyses (see below). To calculate total distance traveled, the great circle distance between daily points was calculated and the total across all days was summed. Mean speed in $\mathrm{km}$ per day was calculated from the rates of movement between points using periods when gaps were no greater than 5 days. Location data were visualized using ArcGIS software (Environmental Systems Research Institute, Redlands, CA).

To examine whether shark size influenced movement behavior, data were separated into two size classes consisting of small $(<165 \mathrm{~cm} \mathrm{FL})$ and large $(\geq 165 \mathrm{~cm} \mathrm{FL})$ mako sharks based on the size at maturity for males. The large-size category ( $>165 \mathrm{~cm} \mathrm{FL)} \mathrm{consisted} \mathrm{of} \mathrm{mostly}$ mature and some large immature males (males mature at 164-191 cm FL [103, 104]), large immature females, and one mature female (females mature at $253-280 \mathrm{~cm} \mathrm{FL}$ $[104,105]$. Kernel density analysis [106] by meteorological season was performed to examine areas of high use for both large and small sharks using the Home Range Tools [107] for ArcGIS 10.1 and 10.2 on tracks lasting at least 1 year. Note that in the later years of the study efforts shifted to tagging larger sharks.

Oceanographic characteristics examined for tracks greater than 1 year in length included depth of the MLD, and satellite-derived SST, primary productivity, and Chl-a concentrations. Mixed layer depth was calculated for recovered PSAT tags using Wildlife Computer's software (WC-DAP). SST, primary productivity $\left(\mathrm{mg} \mathrm{C} \mathrm{m}^{-2}\right.$ day $^{-1}$ ), and Chl-a were extracted for filtered SLRT locations using the R function "xtracto" (package: xtractomatic) [108] and the satellite data in the ERDDAP server at the Environmental Research Division of National Marine Fisheries Service, Southwest Fisheries Science Center [109]. Data were extracted from a region encompassed by an envelope defined by the $\mathrm{X}$ and $\mathrm{Y}$ errors of the location class position estimate error [110], thus matching the scales of the position estimate errors with those of SST, primary productivity, and Chl-a. Data used were monthly composites of MODIS Chl-a, MODIS primary productivity and daily Multi-scale Ultra-high Resolution (MUR) SST.

To compare seasonal migrations of the mako sharks with the seasonal variability of the environmental conditions within the California Current, Hovmöller plots of monthly composites of MODIS SST, MODIS primary productivity and MODIS Chl-a were plotted [111]. The R function "rxtractogon" (package: rerddapXtractomatic) [112] was used to extract satellite data from a region between the North America coastline and $3.85^{\circ}$ west of the coastline (approximately $200 \mathrm{nmi}$ ), between 15 and $47^{\circ} \mathrm{N}$. The data were averaged along longitude to show changing seasonal and annual conditions by latitude within the California Current.

Regional analyses using SLRT tag and PSAT data were performed for five main regions: three regions encompassing the California Current including (1) the SCB; (2) the coastal region north of Point Conception which includes waters off the coasts of northern California, 
Oregon, and Washington; (3) and the west coast of Baja California; (4) and two additional regions including the SOC, which includes the area inside of the SOC and just south along the coast of mainland Mexico; and (5) the offshore region including areas of the North Pacific Subtropical Gyre, NPTZ, and North Equatorial Current. Seasonal utilization, oceanographic conditions, and vertical behavior were analyzed for each of the five regions.

\section{Additional file}

Additional file 1: Table S1. Deployment information. Shark identification (ID), sex ( $M=$ male, $F=$ female, $U=$ unknown), FL (fork length) $\left(^{*}=\right.$ estimated length), deployment location, deployment date, PSAT (pop-up satellite archival tag) pop-update, SLRT (satellite-linked radio-transmitting tags), final date, days at liberty (DAL) PSAT (NR $=$ no report, ${ }^{R}=$ recovered tag), DAL SLRT, average sea surface temperature $(\mathrm{SST})\left({ }^{\circ} \mathrm{C}\right)$, maximum SST $\left({ }^{\circ} \mathrm{C}\right)$, minimum $\mathrm{SST}\left({ }^{\circ} \mathrm{C}\right)$, maximum depth $(\mathrm{m})$, minimum overall temperature $\left({ }^{\circ} \mathrm{C}\right)$

\section{Abbreviations}

Chl-a: chlorophyll a; EEZ: exclusive economic zones; ENP: eastern North Pacific; FL: fork length; IUCN: International Union for Conservation of Nature; MLD: mixed layer depth; MUR: Multi-scale Ultra-high Resolution; NPTZ: North Pacific Transition Zone; PDT: profile of depth and temperature; PSAT: pop-up satellite archival tag; RMSE: Root-mean square error; SCB: Southern California Bight; SLRT: satellite-linked radio-transmitting; SOC: Sea of Cortez; SST: sea surface temperatures; TL: total length; TOPP: Tagging of Pacific Pelagics; YOY: Young-of-the-year.

\section{Acknowledgements}

We thank many colleagues, field assistants, and volunteers from the Southwest Fisheries Science Center, in particular Rand Rasmussen, Darlene Ramon, and Susan Smith who were involved at the conception of the study. We thank the crews of the R/V David Starr Jordon, FN Ventura II, and FN Southern Horizon. Numerous students and colleagues from CICESE, and volunteers from Moss Landing Marine Labs, California State University Fullerton, California State University Long Beach, Monterey Bay Aquarium, Scripps Institution of Oceanography and other institutions assisted during tagging cruises. Keith Poe and Steve Quinlan tagged three large makos for the study. The TOPP Program supplied many tags and maintained data on their server.

\section{Authors' contributions}

This study was initiated and designed by BAB, HD, DBH, SK, and RDV. Electronic tags were deployed on sharks by HD, JRH, MJK, SK, TS, OS, RDV, and JW. Tags were supplied by BAB, DBH, and SK. Data management was performed by HD, SK, NN, and JW. Analyses were conducted and figures were created by HD, MJK, SK, NN, TS, CW, and JW. The manuscript was drafted by NN with the help of HD and SK. All authors read and approved the final manuscript.

\section{Funding}

Funding for this study was provided by National Marine Fisheries Service, the TOPP Program and the NOAA National Cooperative Research Program.

\section{Availability of data and materials}

The datasets used and analyzed during the current study are available from the corresponding author on reasonable request.

\section{Ethics approval and consent to participate}

All mako shark tagging was done in accordance with protocols approved by the Southwest Fisheries Science Center, Institutional Animal Care and Use Committee
Consent for publication

Not applicable.

\section{Competing interests}

The authors declare that they have no competing interests.

\section{Author details}

${ }^{1}$ Southwest Fisheries Science Center, National Marine Fisheries Service, National Oceanic and Atmospheric Administration, San Diego, CA, USA. ${ }^{2}$ Laboratorio de Ecología Pesquera, Departamento de Ecología, CICESE, Ensenada, Baja California, Mexico. ${ }^{3}$ Southwest Fisheries Science Center, National Marine Fisheries Service, National Oceanic and Atmospheric Administration, Monterey, CA, USA. ${ }^{4}$ Hopkins Marine Station, Stanford University, Pacific Grove, CA, USA.

Received: 30 November 2018 Accepted: 27 June 2019

Published online: 15 July 2019

\section{References}

1. Loefer JK, Sedberry GR, McGovern JC. Vertical movements of a shortfin mako in the western North Atlantic as determined by pop-up satellite tagging. Southeastern Nat. 2005;4:237-46.

2. Rogers PJ, Huveneers C, Page B, Goldsworthy SD, Coyne M, Lowther $A D$, Mitchell JG, Seuront L. Living on the continental shelf edge: habitat use of juvenile shortfin makos Isurus oxyrinchus in the Great Australian Bight, southern Australia. Fish Oceanogr. 2015;24:205-18.

3. Vaudo JJ, Wetherbee BM, Wood AD, Weng K, Howey-Jordan LA, Harvey GM, Shivji MS. Vertical movements of shortfin mako sharks Isurus oxyrinchus in the western North Atlantic Ocean are strongly influenced by temperature. Mar Ecol Prog Ser. 2016;547:163-75.

4. Vaudo JJ, Byrne ME, Wetherbee BM, Harvey GM, Shivji MS. Long-term satellite tracking reveals region-specific movements of a large pelagic predator, the shortfin mako shark, in the western North Atlantic Ocean. J Appl Ecol. 2017;4:1765-75.

5. Francis MP, Shivji MS, Duffy CAJ, Rogers PJ, Byrne ME, Wetherbee BM, Tindale SC, Lyon WS, Meyers MM. Oceanic nomad or coastal resident? Behavioural switching in the shortfin mako shark (Isurus oxyrinchus). Mar Biol. 2019;166:5.

6. Carey FG, Scharold JV. Movements of blue sharks (Prionace glauca) in depth and course. Mar Biol. 1990;106:329-42.

7. Holts DB, Bedford DW. Horizontal and vertical movements of the shortfin mako shark, Isurus oxyrinchus, in the Southern California Bight. Aust J Mar Freshw Res. 1993;44:901-9.

8. Klimley AP, Beavers SC, Curtis TH, Jorgensen SJ. Movements and swimming behavior of three species of sharks in La Jolla Canyon, California. Environ Biol Fish. 2002;63:117-35.

9. Vetter R, Kohin S, Preti A, McClatchie S, Dewar H. Predatory interactions and niche overlap between mako shark, Isurus oxyrinchus, and jumbo squid, Dosidicus gigas, in the California Current. Calif Coop Ocean Fish Invest Rep. 2008;49:142-56.

10. Carey FG, Teal JM. Shortfin mako and porbeagle: warm-bodied sharks. Comp Biochem Physiol. 1969;28:199-204.

11. McCosker JE. The white shark, Carcharodon carcharias, has a warm stomach. Copeia. 1987;1987:195-7.

12. Goldman KJ. Regulation of body temperature in the white shark, Carcharodon carcharias. J Comp Physiol B. 1997;167:423-9.

13. Bernal D, Sepulveda C, Graham JB. Water-tunnel studies of heat balance in swimming shortfin mako sharks. J Exp Biol. 2001;204:4043-54.

14. Preti A, Soykan CU, Dewar H, Wells RJD, Spear N, Kohin S. Comparative feeding ecology of shortfin mako, blue and thresher sharks in the California Current. Environ Biol Fish. 2012;95:127-46.

15. Lyons K, Preti A, Madigan DJ, Wells RJD, Blasius ME, Snodgrass OE, Kacev $D$, Harris JD, Dewar H, Kohin S, Mackenzie K. Insights into the life history and ecology of a large shortfin mako shark Isurus oxyrinchus captured in southern California. J Fish Biol. 2015;87:200-11.

16. Sosa-Nishizaki O, Márquez-Farias JF, Villavicencio-Garayzar CJ. Pelagic shark fisheries along the west coast of Mexico. In: Camhi MD, Pikitch EK, BabcockEA, editors. Sharks of the open oceans. Oxford: Blackwell Publishing Ltd.; 2008. p. 275-82. 
17. Cartamil D, Santana-Morales O, Escobedo-Olvera M, Kacev D, CastilloGeniz L, Graham JB, Rubin RD, Sosa-Nishizaki O. The artisanal elasmobranch fishery of the Pacific coast of Baja California, Mexico. Fish Res. 2011;108:393-403.

18. Ramírez-Amaro S, Cartamil D, Galván-Magaña F, Gonzalez-Barba G, Graham JB, Carrera-Fernandez M, Escobar-Sanchez O, Sosa-Nishizaki $\mathrm{O}$, Rochin-Alamillo A. The artisanal elasmobranch fishery of the Pacific coast of Baja California Sur, Mexico, management implications. Sci Mar. 2013;77:473-87.

19. Clarke SC, MCAllister MK, Milner-Gulland EJ, Kirkwood GP, Michielsens CG, Agnew DJ, Pikitch EK, Nakano H, Shivji MS. Global estimates of shark catches using trade records from commercial markets. Ecol Lett. 2006:9:1115-26.

20. Hoenig JM, Gruber SH. Life-history patterns in the elasmobranchs: implications for fisheries management. In: Pratt Jr HL, H, Gruber SH, Taniuchi T, editors, Elasmobranchs as living resources: advances in the biology, ecology, systematics, and the status of the fisheries. NOAA Technical Report 90. 1990; p. 1-16.

21. Au DW, Smith SE, Show C. Shark productivity and reproductive protection, and a comparison with teleosts. In: Camhi MD, Pikitch EK, Babcock EA, editors. Sharks of the open ocean: biology, fisheries and conservation. Oxford: Blackwell Publishing; 2008. p. 298-308.

22. ISC. Stock Assessment of Shortfin Mako Shark in The North Pacific Ocean Through 2016. Annex 5 in Plenary Report of the International Scientific Committee for Tuna and Tuna-like Species in the North Pacific Ocean, Yeosu, Korea; 2018

23. ICCAT. Report of the 2017 ICCAT Shortfin Mako Assessment Meeting. Madrid, Spain; 2017

24. Rigby CL, Barreto R, Carlson J, Fernando D, Fordham S, Francis MP, Jabado RW, Liu KM, Marshall A, Pacoureau N, Romanov E, Sherley RB, Winker H. Isurus oxyrinchus. The IUCN red list of threatened species. 2019; e. T39341A2903170. Accessed 27 Mar 2019.

25. Schrey AW, Heist EJ. Microsatellite analysis of population structure in the shortfin mako (Isurus oxyrinchus). Can J Fish Aquat Sci. 2003;60:670-5.

26. Michaud A, Hyde J, Kohin S, Vetter R. Mitochondrial DNA sequence data reveals barriers to dispersal in the highly migratory shortfin mako shark (Isurus oxyrinchus). ISC/11/SHARKWG-2/03; 2011.

27. Sepulveda C, Kohin S, Chan C, Vetter R, Graham JB. Movement patterns, depth preferences, and stomach temperatures of free swimming juvenile mako shark in the Southern California bight. Mar Biol. 2004:145:191-9.

28. Sippel T, Wraith J, Kohin S, Taylor V, Holdsworth J, Taguchi M, Matsunaga $\mathrm{H}$, Yokawa K. A summary of blue shark (Prionace glauca) and shortfin mako shark (Isurus oxyrinchus) tagging data available from the North and Southwest Pacific Ocean. ISC/11/SHARKWG-2/04; 2011

29. Wells RJ, Smith SE, Kohin S, Freund E, Spear N, Ramon DA. Age validation of juvenile shortfin mako (Isurus oxyrinchus) tagged and marked with oxytetracycline off southern California. Fish Bull. 2013;111:147-60.

30. Pratt HL Jr, Casey JG. Age and growth of the shortfin mako, Isurus oxyrinchus, using four methods. Can J Fish Aquat Sci. 1983:40:1944-57.

31. Hanan DA, Holts DB, Coan AL Jr. The California drift gill net fishery for sharks and swordfish, 1981-1982 through 1990-1991. Fish Bull. 1993;175:1-95.

32. O'Brien JW, Sunada JS. A review of the Southern California experimental drift longline fishery for sharks, 1988-1991. CalCOFI Rep. 1994;35:222-9.

33. Holts DB, Julian F, Sosa-Nishizaki O, Bartoo N. Pelagic shark fisheries along the west coast of the United States and Baja California, Mexico. Fish Res. 1998;39:115-25.

34. Block BA, Jonsen ID, Jorgensen SJ, Winship AJ, Shaffer SA, Bograd SJ, Hazen EL, Foley DG, Breed GA, Harrison AL, Ganong JE. Tracking apex marine predator movements in a dynamic ocean. Nature. 2011;475:86-90

35. Medellín-Ortiz A, Kohin S, Dewar H, Sosa-Nishizaki O, Block B. Movements of the mako shark in the northeastern Pacific. Master thesis, Ensenada Center for Scientific Research and Higher Education, Ensenada, Baja California, México; 2008.

36. Hazen EL, Jorgensen S, Rykaczewski RR, Bograd SJ, Foley DG, Jonsen ID, Shaffer SA, Dunne JP, Costa DP, Crowder LB, Block BA. Predicted habitat shifts of Pacific top predators in a changing climate. Nat Clim Change. 2013:3:234-8
37. Medina-Trujillo EC. Description of the movements of the shortfin mako, Isurus oxyrinchus, in the Northeastern Pacific Ocean using satellite telemetry. Master thesis, Ensenada Center for Scientific Research and Higher Education, Ensenada, Baja California, México; 2013.

38. Kinney MJ, Kacev D, Kohin S, Eguchi T. An analytical approach to sparse telemetry data. PLoS ONE. 2017. https://doi.org/10.1371/journ al.pone.0188660.

39. Watanabe YY, Goldman KJ, Caselle JE, Chapman DD, Papastamatiou YP. Comparative analyses of animal-tracking data reveal ecological significance of endothermy in fishes. Proc Natl Acad Sci. 2015;112:6104-9.

40. Weng KC, O'Sullivan JB, Lowe CG, Winkler CE, Dewar H, Block BA. Movements, behavior and habitat preferences of juvenile white sharks Carcharodon carcharias in the eastern Pacific. Mar Ecol Prog Ser. 2007:338:211-24.

41. Cartamil D, Wegner NC, Kacev D, Ben-Aderet N, Kohin S, Graham JB. Movement patterns and nursery habitat of juvenile thresher sharks Alopias vulpinus in the Southern California Bight. Mar Ecol Prog Ser. 2010;404:249-58.

42. Cartamil D, Wraith J, Wegnern NC, Kacev D, Lam C, Santana-Morales O, Sosa-Nishizaki O, Escobedo-Olvera M, Kohin S, Graham JB, Hastings P. Movements and distribution of juvenile common thresher sharks (Alopias vulpinus) in Pacific coast waters of the USA and Mexico. Mar Ecol Prog Ser. 2016;548:153-63.

43. Klimley AP. The areal distribution and autoecology of the white shark, Carcharodon carcharias, off the west coast of North America. South Calif Acad Sci Mem. 1985;9:15-40.

44. Boustany AM, Matteson R, Castleton M, Farwell C, Block BA. Movements of Pacific bluefin tuna (Thunnus orientalis) in the Eastern North Pacific revealed with archival tags. Prog Oceanogr. 2010;86:94-104.

45. Dewar H, Prince ED, Musyl MK, Brill RW, Sepulveda C, Luo J, Foley D, Orbesen ES, Domeier ML, Nasby-Lucas N, Snodgrass D. Movements and behaviors of swordfish in the Atlantic and Pacific Oceans examined using pop-up satellite archival tags. Fish Oceanogr. 2011:20:219-41.

46. Kitagawa T, Boustany AM, Farwell C, Williams TD, Castleton M, Block BA. Horizontal and vertical movements of juvenile Pacific bluefin tuna (Thunnus orientalis) in relation to seasons and oceanographic conditions. Fish Oceanogr. 2007;16:409-21.

47. McClatchie S. Regional fisheries oceanography of the California Current system. New York: Springer; 2014.

48. Zwolinski JP, Emmett R, Demer DA. Predicting habitat to optimize sampling of Pacific sardine (Sardinops sagax). ICES J Mar Sci. 2011;68:867-79.

49. Lluch-Belda D, Lluch-Cota DB, Lluch-Cota SE. Baja California's biological transition zones: refuges for the California sardine. J Oceanogr. 2003;59:503-13.

50. Domeier ML, Nasby-Lucas N. Two-year migration of adult female white sharks (Carcharodon carcharias) reveals widely separated nursery areas and conservation concerns. Anim Biotelem. 2013;1:1-9.

51. Oñate González EC, Sosa Nishizaki O, Herzka Llona SZ, Lowe CG, Lyons K, Santana Morales O, Sepúlveda C, Guerrero Avila C, García Rodríguez E, O'Sullivan JB. Importance of Bahia Sebastian Vizcaino as a nursery area for white sharks (Carcharodon carcharias) in the Northeastern Pacific: a fishery dependent analysis. Fish Res. 2017;188:125-37.

52. Salomón-Aguilar CA, Villavicencio-Garayzar CJ, Reyes-Bonilla H. Shark breeding grounds and seasons in the Gulf of California: fishery management and conservation strategy. Ciencias Marinas. 2009;35:369-88.

53. Jorgensen SJ, Reeb CA, Chapple TK, Anderson S, Perle C, Van Sommeran SR, Fritz-Cope C, Brown AC, Klimley AP, Block BA. Philopatry and migration of Pacific white sharks. Proc R Soc B Biol Sci. 2010;277:679-88.

54. Domeier ML, Nasby-Lucas N. Sex specific migration patterns and sexual segregation for adult white sharks in the northeastern Pacific. In: Domeier ML, editor. Global perspectives on the biology and life history of the white shark. Boca Raton: CRC Press; 2012. p. 133-46.

55. Pennington JT, Mahoney KL, Kuwahara VS, Kolber DD, Calienes R, Chavez FP. Primary production in the eastern tropical Pacific: a review. Prog Oceanogr. 2006;69:285-317.

56. Holland KN, Grubbs RD. Fish visitors to seamounts: tunas and bill fish at seamounts. In: Haggan N, Morato T, Santos RS, Hart PJB, Clark MR, editors. Seamounts: ecology, fisheries \& conservation. Oxford: Blackwell Scientific; 2007. p. 189-201.

57. Garcia HE, Locarnini RA, Boyer TP, Antonov Jl. World Ocean Atlas. Volume 3: dissolved oxygen, apparent oxygen utilization, and oxygen 
saturation. In: Levitus S, editor. NOAA Atlas NESDIS, vol. 63. Washington, DC: U.S. Government Printing Office; 2005. p. 2006.

58. Polovina JJ, Howell E, Kobayashi DR, Seki MP. The transition zone chlorophyll front, a dynamic global feature defining migration and forage habitat for marine resources. Prog Oceanogr. 2001:49:469-83.

59. Robinson PW, Costa DP, Crocker DE, Gallo-Reynoso JP, Champagne CD, Fowler MA, Goetsch C, Goetz KT, Hassrick JL, Hückstädt LA, Kuhn CE. Foraging behavior and success of a mesopelagic predator in the northeast Pacific Ocean: insights from a data-rich species, the northern elephant seal. PLoS ONE. 2012;1:11-3. https://doi.org/10.1371/journ al.pone.0036728.

60. Sippel T, Ohshimo, S, Yokawa K, Kai M, Carvalho F, Liu KM, Castillo-Géniz L, Kohin S. Spatial and temporal patterns of shortfin mako shark size and sex in the North Pacific Ocean. ISC/15/SHARKWG-1/04; 2015.

61. Lea JS, Wetherbee BM, Queiroz N, Burnie N, Aming C, Sousa LL, Mucientes GR, Humphries NE, Harvey GM, Sims DW, Shivji S. Repeated, long-distance migrations by a philopatric predator targeting highly contrasting ecosystems. Sci Rep. 2015;5:11202.

62. Weng KC, Castilho PC, Morrissette JM, Landeira-Fernandez AM, Holts DB, Schallert RJ, Goldman KJ, Block BA. Satellite tagging and cardiac physiology reveal niche expansion in salmon sharks. Science. 2005:310:104-6.

63. Gaspar P, Benson SR, Dutton PH, Réveillère A, Jacob G, Meetoo C, Dehecq A, Fossette $S$. Oceanic dispersal of juvenile leatherback turtles: going beyond passive drift modeling. Mar Ecol Prog Ser. 2012;457:265-84.

64. Hoey JJ. Analysis of longline fishing effort for apex predators (swordfish, shark, and tuna) in the western North Atlantic and Gulf of Mexico. Ph.D. Dissertation, University of Rhode Island, Kingston; 1983.

65. Casey JG, Kohler NE. Tagging studies on the shortfin mako shark (Isurus oxyrinchus) in the western North Atlantic. Aust J Mar Freshw Res. 1992;43:45-60.

66. Sims DW. Differences in habitat selection and reproductive strategies of male and female sharks. In: Ruckstuhl KE, Neuhaus P, editors. Sexual Segregation in Vertebrates: Ecology of the Two Sexes. Cambridge: Cambridge University Press; 2005. p. 127-47.

67. Goldman KJ, Musick JA. Growth and maturity of salmon sharks (Lamna ditropis) in the eastern and western North Pacific, and comments on back-calculation methods. Fish Bull. 2006;104:278-92.

68. Nakano H, Stevens JD. The biology and ecology of the blue shark, Prionace glauca. In: Camhi MD, Pikitch EK, editors. Sharks of the open ocean: Biology, fisheries and conservation. Oxford: Blackwell; 2008. p. 140-51.

69. Mucientes GR, Queiroz N, Sousa LL, Tarroso P, Sims DW. Sexual segregation of pelagic sharks and the potential threat from fisheries. Biol Lett. 2009;5:156-9.

70. Domenici P. The scaling of locomotor performance in predator-prey encounters: from fish to killer whales. Comp Biochem Physiol A. 2001;131:169-82.

71. Domeier ML. A new life-history hypothesis for white sharks, Carcharodon carcharias, in the Northeastern Pacific. In: Domeier ML, editor. Global perspectives on the biology and life history of the white shark. Boca Raton: CRC Press; 2012. p. 199-224.

72. Holland KN, Brill RW, Chang RK, Sibert JR, Fournier DA. Physiological and behavioural thermoregulation in bigeye tuna (Thunnus obesus). Nature. 1992;358:410

73. Dewar H, Domeier M, Nasby-Lucas N. Insights into the young of the year white shark (Carcharodon carcharias), behavior in the Southern California Bight. Environ Biol Fish. 2004;70:133-43.

74. Meyer CG, Holland KN, Papastamatiou YP. Sharks can detect changes in the geomagnetic field. J R Soc Interface. 2005;2:129-30.

75. Horton TW, Hauser N, Zerbini AN, Francis MP, Domeier ML, Andriolo A, Costa DP, Robinson PW, Duffy CAJ, Nasby-Lucas N, Holdaway RN, Clapham PJ. Route fidelity during marine megafauna migration. Front Mar Sci. 2017:4:422

76. Weng KC, Block BA. Diel vertical migration of the bigeye thresher shark (Alopias superciliosus), a species possessing orbital retia mirabilia. Fish Bull. 2004;102:221-9.

77. Nasby-Lucas N, Dewar H, Lam CH, Goldman KJ, Domeier ML. White shark offshore habitat: a behavioral and environmental characterization of the eastern Pacific shared offshore foraging area. PLoS One. 2009. https://doi.org/10.1371/journal.pone.0008163.
78. Cartamil D, Sepulveda CA, Wegner NC, Aalbers SA, Baquero A, Graham JB. Archival tagging of subadult and adult common thresher sharks (Alopias vulpinus) off the coast of southern California. Mar Biol. 2011;158:935-44.

79. Coffey DM, Carlisle AB, Hazen EL, Block BA. Oceanographic drivers of the vertical distribution of a highly migratory, endothermic shark. Sci Rep. 2017;7:10434.

80. Domeier ML, Nasby-Lucas N, Palacios DM. The Northeastern Pacific white shark Shared Offshore Foraging Area (SOFA). In: Domeier ML, editor. Global perspectives on the biology and life history of the white shark. Boca Raton: CRC Press; 2012. p. 147-58.

81. Prince ED, Goodyear CP. Hypoxia-based habitat compression of tropical pelagic fishes. Fish Oceanogr. 2006;2006(15):451-64.

82. Taylor NG, McAllister MK, Lawson GL, Carruthers T, Block BA. Atlantic bluefin tuna: a novel multistock spatial model for assessing population biomass. PLoS One. 2011. https://doi.org/10.1371/journal.pone.00276 93.

83. Sippel T, Eveson JP, Galuardi B, Lam C, Hoyle S, Maunder M, Kleiber P, Carvalho F, Tsontos V, Teo SL, Aires-da-Silva A. Using movement data from electronic tags in fisheries stock assessment: a review of models, technology and experimental design. Fish Res. 2015;163:152-60.

84. Kerr LA, Cadrin SX, Secor DH, Taylor NG. Modeling the implications of stock mixing and life history uncertainty of Atlantic bluefin tuna. Can J Fish Aquat Sci. 2016;74:1990-2004.

85. Bigelow KA, Hampton J, Miyabe N. Application of a habitat-based model to estimate effective longline fishing effort and relative abundance of Pacific bigeye tuna (Thunnus obesus). Fish Oceanogr. 2002;11:143-55.

86. Dewar H, Eguchi T, Hyde J, Kinzey D, Kohin S, Moore J, Taylor BL, Vetter R. Status review of the northeastern Pacific population of white sharks (Carcharodon carcharias) under the Endangered Species Act. National Oceanic and Atmospheric Administration, National Marine Fisheries Service, Southwest Fisheries Science Center, La Jolla, CA; 2013.

87. Evans K, Abascal F, Kolody D, Sippel T, Holdsworth J, Maru P. The horizontal and vertical dynamics of swordfish in the South Pacific Ocean. J Exp Mar Biol Ecol. 2014;450:55-67.

88. Corrigan S, Lowther AD, Beheregaray LB, Bruce BD, Cliff G, Duffy CA, Foulis A, Francis MP, Goldsworthy SD, Hyde JR, Jabado RW, Kacev D, Marshall L, Mucientes GR, Naylor GJP, Pepperell JG, Queiroz N, White WT, Wintner SP, Rogers PJ. Population connectivity of the highly migratory shortfin mako (Isurus oxyrinchus Rafinesque 1810) and implications for management in the Southern Hemisphere. Front Ecol Evol. 2018:6:187.

89. ISC. Indicator-based analysis of the status of shortfin mako shark in the North Pacific Ocean. Annex 12 in Plenary Report of the International Scientific Committee for Tuna and Tuna-like Species in the North Pacific Ocean, Kona, Hawaii, U.S.A.; 2015.

90. Queiroz N, Humphries NE, Mucientes G, Hammerschlag N, Lima FP, Scales KL, Miller PI, Sousa LL, Seabra R, Sims DW. Ocean-wide tracking of pelagic sharks reveals extent of overlap with longline fishing hotspots. Proc Natl Acad Sci. 2016;113:1582-7.

91. Watson JW, Kerstetter DW. Pelagic longline fishing gear: a brief history and review of research efforts to improve selectivity. Mar Technol Soc J. 2006:40:6-11

92. Howell EA, Kobayashi DR, Parker DM, Balazs GH, Polovina JJ. TurtleWatch: a tool to aid in the bycatch reduction of loggerhead turtles Caretta caretta in the Hawaii-based pelagic longline fishery. End Spec Res. 2008;5:267-78.

93. Walsh WA, Bigelow KA, Sender KL. Decreases in shark catches and mortality in the hawaii-based longline fishery as documented by fishery observers. Mar Coastal Fish. 2009;1:270-82.

94. Sosa-Nishizaki O, Saldaña-Ruiz LE, Corro-Espinosa D, Tovar-Ávila J, Castillo-Géniz JL, Santana-Hernández H, Márquez-Farías JF. Estimations of the Shortfin Mako Shark (Isurus oxyrinchus) catches by Mexican Pacific fisheries, An update (1976-2016). ISC/17/SHARKWG-3/19; 2017.

95. Velez-Marin R, Marquez-Farias JF. Distribution and size of the shortfin mako (Isurus oxyrinchus) in the Mexican Pacific Ocean. Panam J Aquat Sci. 2009:4:490-9.

96. Castillo-Géniz L, Godinez-Padilla J, Ajas-Terriquez H, Gonzalez-Ania L. Catch data for shortfin mako shark reported by fishery observers from Mexican shark longline and drift gillnet fisheries in the North Pacific in 2006-2014. 2014;ISC/14/SHARKWG-3/02. 
97. Runcie R, Holts D, Wraith J, Xu Y, Ramon D, Rasmussen R, Kohin S. A fishery-independent survey of juvenile shortfin mako (Isurus oxyrinchus) and blue (Prionace glauca) sharks in the Southern California Bight, 1994-2013. Fish Res. 2016;183(233-24):3.

98. Wildlife Computers. Location Processing (GPE3 \& Fastloc ${ }^{\circledR}$ ) in the Wildlife Computers Data Portal User Guide (https://wildlifecomputers.com/ wp-content/uploads/manuals/Location-Processing-User-Guide.pdf). Accessed 28 April 2019.

99. Lam CH, Nielsen A, Sibert JR. Improving light and temperature based geolocation by unscented Kalman filtering. Fish Res. 2008;91:15-25.

100. Pedersen MW, Patterson TA, Thygesen UH, Madsen H. Estimating animal behavior and residency from movement data. Oikos. 2011;120:1281-90.

101. Basson M, Bravington MV, Hartog JR, Patterson TA. Experimentally derived likelihoods for light-based geolocation. Methods Ecol Evol. 2016;7:980-9.

102. Jacobson L, Seaver A, Tang J. AstroCalc4R: software to calculate solar zenith angle; time at sunrise, local noon and sunset; and photosynthetically available radiation based on date, time and location. U.S Department of Commerce, Northeast Fish Science Center Reference Document. 2011; pp. 11-14.

103. Conde-Moreno M, Galvan-Magaña F. Reproductive biology of the mako shark Isurus oxyrinchus on the south-western coast of Baja California, Mexico. Cybium. 2006;30:75-83.

104. Joung SJ, Hsu HH. Reproduction and embryonic development of the shortfin mako, Isurus oxyrinchus Rafinesque, 1810, in the Northwestern Pacific. Zool Stud Taipei. 2005;44:487-96.

105. Semba Y, Aoki I, Yokawa K. Size at maturity and reproductive traits of shortfin mako, Isurus oxyrinchus, in the western and central North Pacific. Mar Freshw Res. 2011;62:20-9.
106. Worton BJ. Kernel methods for estimating the utilization distribution in home-range studies. Ecology. 1989;70:164-8.

107. Rodgers AR, Kie JG, Wright D, Beyer HL, Carr AP. HRT: Home Range Tools for ArcGIS. Version 2.0. Ontario Ministry of Natural Resources and Forestry, Centre for Northern Forest Ecosystem Research, Thunder Bay, Ontario, Canada; 2015.

108. Mendelssohn R. xtractomatic: accessing environmental data from ERD's ERDDAP server. R package version 3.4.2. 2018. https://CRAN.R-proje ct.org/package=xtractomatic. Accessed 11 July 2019

109. Simons, R.A. ERDDAP, NOAA Southwest Fisheries Science Center Monterey, CA: NOAA/NMFS/SWFSC/ERD. 2019. http://coastwatch.pfeg.noaa. gov/erddap. Accessed 21 Feb 2019.

110. Vincent C, McConnell BB, Ridoux V, Fedak M. Assessment of Argos location accuracy from satellite tags deployed on captive gray seals. Mar Mamm Sci. 2002;18:156-66.

111. Hovmöller Ernest. The trough-and-ridge diagram. Tellus. 1949;1:62-6.

112. Mendelssohn R. rerddapXtracto: extracts environmental data from 'ERDDAP' web services. R package version 0.3.5. 2019. https://CRAN.R-proje ct.org/package=rerddapXtracto. Accessed 11 July 2019.

\section{Publisher's Note}

Springer Nature remains neutral with regard to jurisdictional claims in published maps and institutional affiliations.
Ready to submit your research? Choose BMC and benefit from:

- fast, convenient online submission

- thorough peer review by experienced researchers in your field

- rapid publication on acceptance

- support for research data, including large and complex data types

- gold Open Access which fosters wider collaboration and increased citations

- maximum visibility for your research: over 100M website views per year

At BMC, research is always in progress.

Learn more biomedcentral.com/submissions 